DOE/EA-1231

\title{
ENVIRONMENTAL ASSESSMENT \\ FOR THE REUSE OF TNX \\ AS A \\ MULTI-PURPOSE PILOT PLANT CAMPUS \\ AT THE SAVANNAH RIVER SITE
}

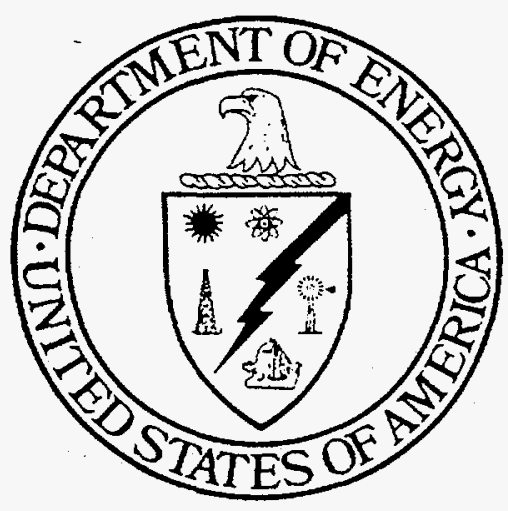

JULY 1998

U. S. DEPARTMENT OF ENERGY

SAVANNAH RIVER OPERATIONS OFFICE

SAVANNAH RIVER SITE

MASTER

SAVANNAH RIVER SITE

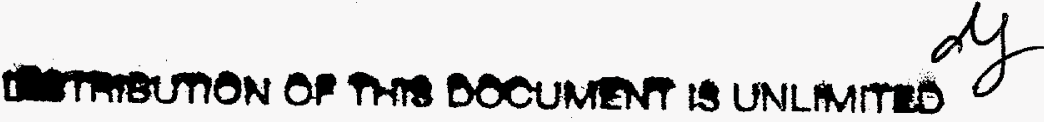


This page left intentionally blank. 


\section{DISCLAIMER}

Portions of this document may be illegible electronic image products. Images are produced from the best available original document. 


\section{Finding of No Significant Impact \\ for the \\ Reuse of TNX as a \\ Multi-Purpose Pilot Plant Campus \\ at the Savannah River Site}

Agency: $\quad$ U.S. Department of Energy

Action: $\quad$ Finding of No Significant Impact

Summary: In accordance with The National Environmental Policy Act (NEPA) of 1969, as amended; the requirements of the Council on Environmental Quality Regulations for Implementing NEPA (40 CFR Parts 1500-1508); and the Department of Energy (DOE) Regulations for Implementing NEPA (10 CFR Part 1021), DOE has prepared an environmental assessment (EA) (DOE/EA-1231) to analyze the potential environmental and safety impacts of DOE planning to allow asset reuse of the TNX Area at the Savannah River Site (SRS) located near Aiken, South Carolina. Based on the analyses in the EA, DOE has determined that the proposed action is not a major Federal action significantly affecting the human environment within the meaning of the National Environmental Policy Act (NEPA) of 1969. Therefore, the preparation of an environmental impact statement (EIS) is not required, and DOE is issuing this Finding of No Significant Impact (FONSI).

Public Availability: Copies of the EA and FONSI or further information on the DOE NEPA process are available from:

Andrew R. Grainger

NEPA Compliance Officer

Savannah River Operations Office

773-42A, Rm. 212

Aiken, South Carolina 29808

Phone/Fax: (800) 881-7292

e-mail: nepa@srs.gov

Background: Congress passed enabling legislation for DOE Savannah River Operations Office (SR) to establish an International Center for Applied Research (ICAR) in Fiscal Year 1995 (Section 3140 of the Fiscal Year 1995 National Defense Authorization Act). The focus of ICAR included the research and development (R\&D) of any technologies that the Secretary considers appropriate and that are likely to be commercialized. There is a great need for the development, demonstration, and commercialization of the next generation of technologies in the environmental restoration and management mission areas, nuclear and non-nuclear. To meet the legislative intent, DOE-SR has established four program areas which will be called Centers of Excellence.
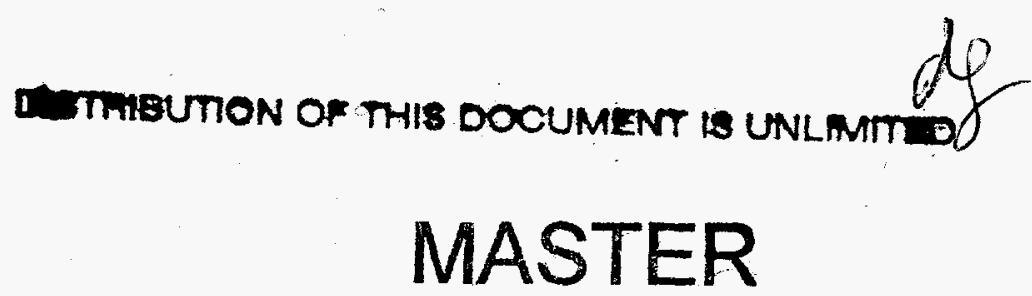
These program areas are soil remediation, groundwater contamination, municipal solid waste minimization, and radioecology [to be located at the Savannah River Ecology Laboratory (SREL) at SRS, but managed from the proposed Multi-Purpose Pilot Plant Campus (MPPC) at TNX]. An applied research program would be established in each area which has a coherence of focus and deals quantitatively with the risks associated with the problems to be investigated. R\&D would be conducted mainly by university partnerships, each having an industrial partner to ensure the technical feasibility of developing a technology that can be economically commercialized. Centers of Excellence activities would be managed by a Board of Directors. In order to meet these needs, DOE-SR plans to set aside the MPPC (formerly known as "TNX") for the location of the Centers of Excellence administrative headquarters, facilities for demonstrations, and the development and nurturing of industrial partnerships. The types of activities and business that are planned at the MPPC would include R\&D in the areas of environmental remediation; waste management and vitrification of non-radioactive waste; metal fabrication and machining operations; and production of chemicals and polymers. Some pilot-scale or small-scale manufacturing is expected. The TNX Area is located 0.8 kilometers $(0.5$ miles $)$ east of the Savannah River on an upland terrace between Upper Three Runs to the north and Fourmile Branch to the south of South Carolina Route 125 near SRS.

The TNX Area (called TNX Semi-works) was used as a staging area for receipt and testing of large process equipment destined for use in production facilities within SRS. Since 1978, the TNX Area has expanded from 3 original buildings constructed in 1950, to 32 buildings that are currently located within the 5.7 hectare (14 acre) fenced area. These 32 buildings include administrative offices, process buildings for large-scale experimental demonstrations, laboratories for both research and analytical work, pilot-scale facilities, bulk tank storage, industrial wastewater processing facilities, and warehouse storage for a wide range of chemical and specialty equipment. Some areas within Buildings 677-T and 678-T contain radiological contamination from depleted uranium. Administrative and institutional controls would be in place to prevent contact between workers and contaminated equipment before occupancy of these buildings. No new radiological operations are planned for TNX. There is an adequate infrastructure (water, sewer, electric, steam, and compressed air) to perform a multitude of activities.

Several facilities located adjacent to the TNX Area are outside the fenced area and are therefore not part of the scope being evaluated within this EA. These are an abandoned sanitary sewer tile field to the south, the new TNX Seepage Basin to the east, the Kaolin Settling Basin to the north, the old TNX Seepage Basin Discharge Gully, Outfall Delta, and TNX wetlands to the west. The TNX Sanitary Treatment Plant (STP) and TNX Effluent Treatment Plant (ETP) are separately fenced and considered to be a part of the TNX Area.

Currently the TNX Area is used primarily for Defense Waste, Interim Waste and Environmental Sciences programs conducted by the Savannah River Technology Center (SRTC). In addition, the facility hosts other programs which are sponsored by DOE-SR, SRTC, and the Westinghouse Savannah River Company Community Outreach Division. The TNX Area also supports technology transfer initiatives through Cooperative Research and Development Agreements 
(CRADAs) with private industry. These existing, funded activities will continue to operate at the TNX as a sub-lessee to a proposed new management firm of the TNX Area.

Proposed Action: The proposed action is for DOE-SR to contract (through a cooperative agreement) with a non-profit entity to serve as a management firm to administer, operate, and market (as well as sub-lease) the TNX facilities and equipment [including 32 buildings, trailers, warehouses, etc., within 5.7 hectares (14 acres)]. Major activities which could be conducted in the area would be: 1) used as a location for technology research, development, demonstration, and commercial operations; 2) used to establish partnerships with industry to develop applied technologies for commercialization; and 3) establish and operate Centers of Excellence in the program areas of soil remediation, groundwater contamination, municipal solid waste minimization, and radioecology (to be located elsewhere on SRS and not part of this action except for administrative functions).

The potential management firm would be responsible for determining and implementing the strategy for executing a program whose objectives include the administration and operation of the facilities and equipment at the MPPC in accordance with the types of activities and businesses outlined in the EA (DOE/EA-1231). The management firm would not be responsible for remediation, environmental restoration, surveillance, and maintenance costs associated with legacy hazardous or radioactive materials at the facility. The management firm would be responsible for any new contamination or releases to the environment. Any non-legacy contamination (hazardous or non-hazardous) that results from the management firm's operations (as well as a sub-lessee) would be the responsibility of the management firm, not DOE-SR. DOE-SR anticipates that the management firm would attain self-sufficiency within three years. The proposed action would also allow DOE-SR to meet its objectives of preserving the TNX Area for future site support missions.

Alternatives: In accordance with NEPA regulations, DOE-SR examined the following alternatives to the proposed action:

- No Action: Not Privatize (Asset Reuse) and Not Establish the Centers of Excellence at TNX

This would consist of DOE-SR not carrying out a priority privatization mission under the ICAR legislative mandate and funding made available by the Congress to establish partnerships for environmental technology commercialization development at a location which could provide significant infrastructure for the Centers of Excellence. This alternative would not enable DOE-SR to preserve the TNX Area for future SRS support missions as the facilities would remain underutilized and not cost effective. A "Transition" Plan would be implemented to eventually deactivate the facilities.

\section{- Establish the Centers of Excellence at Other DOE-SR Facilities}

This alternative would implement the proposed action at a different location on SRS. Areas such as $\mathrm{M}$ Area or the reactor areas were possible candidates as they have been preliminarily evaluated by DOE-SR for limited asset reuse. This alternative was rejected as these areas do not provide ready access for commercial activities, contain additional contamination, and lack the 
necessary infrastructure such as the administrative office space, laboratory facilities, process water, and segregated sanitary and waste facilities. These areas are also not near a major public access making materials transportation more difficult and are not close to the Three Rivers Solid Waste Authority Regional Landfill, located near TNX on South Carolina Route 125, where the coordination and management of municipal solid waste technology development and commercialization is expected to occur. Also, Environmental Baseline Surveys may be required for leasing of DOE-SR property and have not been initiated for these areas.

\section{- Support Similar ICAR Efforts Offsite Within the Five-County Area}

Another alternative would be to implement the proposed action at other offsite locations within the five-county area (Columbia, Richmond, Aiken, Allendale, and Barnwell Counties). This alternative was rejected because it would not allow direct study of in situ site contamination and the development of site-specific cleanup technologies to bring to commercialization. Also, there are not enough funds provided in the ICAR legislation budget to fund new facilities either on or offsite. There are also insufficient laboratory facilities within the five-county area to support the project and needed access to cleanup technologies being developed and obtaining materials for research located at the Three Rivers Solid Waste Authority Regional Landfill would be more difficult if the Centers were located away from SRS.

Environmental Impacts: Impacts from the proposed action would be those effects associated with the emissions, effluents, and wastes from multiple sources from the numerous lessees operations. The management firm contractor and its tenants would be required to operate in compliance with all applicable SRS permits, unless alternate administrative arrangements can be made. Any plans for expansion of existing facilities or processes would require review and approval by DOE-SR prior to the required additional NEPA reviews. Any plans or processes, which involve hazardous activities, would require approval by the DOE-SR Safety Division. The management firm and WSRC will enter into a memorandum of understanding to delineate responsibilities.

DOE-SR would provide the oversight for compliance activities related to requirements for OSHA and work classification standards. As a result of external reviews (by any organization other than the management firm), issues and findings shall be addressed by the management firm and corrective action plans must be prepared and implemented. The management firm would be responsible for compliance with all Federal and State laws and regulations. The management firm shall ensure that the sub-lessees of facilities comply with OSHA (29 CFR Part 1910), NFPA 101 Life Safety Codes and applicable Federal and State laws and regulations and applicable DOE Orders (if any).

DOE-SR would require the management firm, as part of the contract instrument, to ensure sub-lessees of facilities submit an Environment, Safety, and Health (ES\&H) Plan that includes the ES\&H standards and requirements that would be applied in the conduct of work under the agreement. The ES\&H Plan would be developed based on the scope of work and associated hazards to provide adequate protection for the health and safety of workers, the public, and the environment. DOE-SR would retain the discretion to check on the management firm to ensure 
its performance meets the requirements provided in the plan and will reserve authority to terminate the agreement in the event of unsatisfactory performance.

Effluents/emissions from the activities of the management firm and its tenants will not be allowed to exceed permitted limits. Any desired deviations from SRS permit requirements would require DOE-SR and State approval. The management firm will be responsible for reporting and responding to all non-permitted environmental releases.

There would be minimal effect on the local economy with some increase in the purchases of materials and supplies from the proposed action. No additional adverse impacts are expected to either the site surface or groundwater quality. Resource Conservation and Recovery Act/ Comprehensive Environmental Response, Compensation, and Liability Act (RCRA/CERCLA) remedial actions would proceed under the Federal Facilities Agreement (FFA) schedule with administrative and institutional controls in place to assure minimum health and safety risks to workers and non-interference between lessee's operations and environmental restoration activities. The proposed action would have no adverse effects on threatened and endangered species, cultural resources, floodplain, or wetlands at SRS. Additional impacts to local air and water quality would be negligible. Any plans for expansion of existing facilities or processes would be reviewed and approved by DOE-SR and require appropriate permits and additional NEPA reviews. The MPPC would be required to be monitored for ES\&H requirements through an ES\&H Plan. The requirements are the same as the site's in order to assure that there are no additional potential problems for either public health or safety. There would be no change in the latent fatal cancers within the region as the result of the proposed action. Any increases in site traffic accident and fatality rates would be minimal as the result of the proposed action.

Determination: Based on the information and analyses in the attached EA (DOE/EA-1231), and the receipt of no comments from stakeholders (including the States of Georgia and South Carolina), DOE has determined that the proposed reuse of the TNX facilities as a multi-purpose pilot plant campus for the location for technology research, demonstrations, development of industrial partnerships, and commercial operations at SRS does not constitute a major Federal action significantly affecting the quality of the human environment within the meaning of NEPA. Therefore, an EIS is not required and DOE is issuing this FONSI.

Signed in Aiken, South Carolina, this $2 \stackrel{N \Phi}{=}$ day of $\int u L y, 1998$.

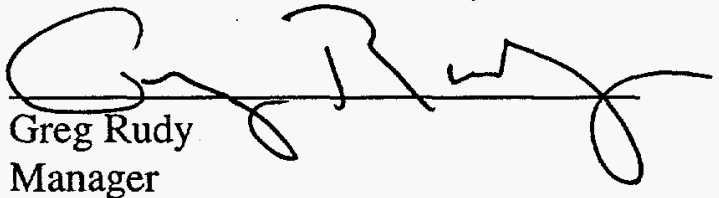

Savannah River Operations Office 
TABLE OF CONTENTS

$\begin{array}{lll}1.0 & \text { INTRODUCTION } & 1\end{array}$

1.1 Background 3

1.1.1 Centers of Excellence 3

1.1.2 TNX Area 3

1.1.2.1 Operational Facilities $\quad 4$

1.1.2.2 Excluded Facilities 9

$\begin{array}{lll}1.2 & \text { Purpose and Need for Action } & 10\end{array}$

$\begin{array}{llr}2.0 & \text { PROPOSED ACTION AND ALTERNATIVES } & 10\end{array}$

$\begin{array}{lll}2.1 & \text { Proposed Action } & 10\end{array}$

2.1.1 Management Firm Responsibilities 11

2.1.2 Centers of Excellence 11

2.2 Alternatives to the Proposed Action 12

2.2.1 No Action, Not Privatize and Not Establish the 12 Centers of Excellence at TNX

2.2.2 Establish the Centers of Excellence at Other DOE-SR 12 Facilities

2.2.3 Support Similar ICAR Efforts Offsite Within the 12 Five-County Area

$\begin{array}{lll}3.0 & \text { AFFECTED ENVIRONMENT } & 13\end{array}$

$\begin{array}{lll}\text { 3.1. Site Conditions } & 13\end{array}$

3.1.1 Land Use 13

3.1.2 Meteorology and Climatology 13

3.1.3 Geology and Seismology 13

3.1.4 Hydrology 14

3.1.5 Ecological and Cultural Resources 14

3.1.6 Radiation Environment 15

$\begin{array}{lll}3.2 & \text { TNX Conditions } & 15\end{array}$ 


\section{TABLE OF CONTENTS (CONT'D)}

3.2.1 Air Quality

3.2.2 Water Quality

3.2.2.1 Domestic Water

3.2.2.2 Fire Water

3.2.2.3 Stormwater

3.2.2.4 Surface Water Quality

3.2.2.5 Process Water

3.2.2.6 Industrial Wastewater

3.2.2.7 Sanitary Wastewater

3.2.2.8 Groundwater

$\begin{array}{ll}\text { 3.2.3 Waste Cleanup } & 20\end{array}$

3.2.3.1 RCRA/CERCLA Units 20

3.2.3.2 Site Evaluation Areas 21

$\begin{array}{lll}3.2 .3 .3 & \text { Spills } & 22\end{array}$

3.2.4 Hazardous Materials and Toxic Substances 22

3.2.4.1 PCBs 22

3.2.4.2 Asbestos 23

3.2.4.3 Heavy Metals 23

3.2.4.4 Chemicals 24

3.2.5 Radiological 24

3.2.6 Waste Management 25

3.2.6.1 Solid Waste 25

3.2.6.2 Hazardous Waste 25

3.2.6.3 Radioactive Waste 25

4.0 ENVIRONMENTAL CONSEQUENCES OF THE PROPOSED 26 ACTION AND ALTERNATIVES

4.1 Safety and Health Impacts $\quad 26$

4.2 Human Health Impacts 31

4.3 Environmental Consequences of the Alternatives 32

4.4 Cumulative Impacts 32 
5.0 REGULATORY AND PERMITTING PROVISIONS CONSIDERED

5.1 National Environmental Policy Act of 1969 as amended 33

5.2 Environmental Baseline Survey: Summary of TNX

Regulatory Compliance Activities

6.0 AGENCIES AND PERSONS CONSULTED 34

$\begin{array}{lll}7.0 & \text { REFERENCES } & 35\end{array}$

$\begin{array}{ll}\text { LIST OF FIGURES } & \text { Page }\end{array}$

Figure 1-1. Location of the Multi-Purpose Pilot Plant Campus 2

(formerly TNX) at the Savannah River Site, South Carolina

Figure 1-2. TNX Area: Location of Buildings

Figure 1-3. Aerial Photo of TNX Area 6 


\section{List of Abbreviations/Acronyms}

The following is an alphabetized list of the abbreviations and acronyms found within the text of this document:

$\begin{array}{ll}\text { AM/CM } & \text { Americium/Curium Melter } \\ \text { BMP } & \text { Best Management Practice } \\ \text { BOD } & \text { Biological Oxygen Demand } \\ \text { BRA } & \text { Baseline Risk Assessment } \\ \text { CA } & \text { Contamination Area } \\ \text { CAA } & \text { Clean Air Act } \\ \text { CERCLA } & \text { Comprehensive Environmental Response, Compensation, and Liabilities } \\ & \text { Act } \\ \text { CERFA } & \text { Community Environmental Response Facilitation Act } \\ \text { CFR } & \text { Code of Federal Regulations } \\ \text { COC } & \text { Constituent of Concern } \\ \text { COD } & \text { Chemical Oxygen Demand } \\ \text { COPC } & \text { Constituent of Potential Concern } \\ \text { CEQ } & \text { Council on Environmental Quality } \\ \text { CIIS } & \text { Chemical Information and Inventory System } \\ \text { CMCOPC } & \text { Contaminant Migration Constituent of Potential Concern } \\ \text { CRADA } & \text { Cooperative Research and Development Agreement } \\ \text { CVOCs } & \text { Chlorinated Volatile Organic Compounds } \\ \text { DETOX } & \text { Detoxification Process } \\ \text { DOE } & \text { U. S. Department of Energy } \\ \text { DOE-SR } & \text { Department of Energy-Savannah River } \\ \text { DOT } & \text { U. S. Department of Transportation } \\ \text { DWPF } & \text { Defense Waste Processing Facility } \\ \text { EA } & \text { Environmental Assessment } \\ \text { EBS } & \text { Environmental Baseline Survey } \\ \text { EEC } & \text { Environmental Evaluation Checklist } \\ \text { EIS } & \text { Environmental Impact Statement } \\ \text { EPCRA } & \text { Emergency Planning and Community Right-to-Know Act } \\ \text { ES\&H } & \text { Environment, Safety and Health } \\ \text { ETP } & \text { Effluent Treatment Plant (TNX) } \\ \text { FFA } & \text { Federal Facility Agreement } \\ \text { FONSI } & \text { Finding of No Significant Impact } \\ \text { FOSL } & \text { Finding of Suitability to Lease } \\ \text { FS/CMS } & \text { Feasibility Study/Corrective Measures Study } \\ \text { GFD } & \text { Geometrically Favorable Dissolver } \\ \text { GWOU } & \text { Groundwater Operable Unit } \\ \text { HAZMAT } & \text { Hazardous Materials } \\ \text { HCA } & \text { High Contamination Area } \\ \text { HEC } & \text { Hazardous Energy Control } \\ & \end{array}$




\section{List of Acronyms (Cont'd)}

$\begin{array}{ll}\text { HGCA } & \text { Hybrid Groundwater Corrective Action } \\ \text { HLW } & \text { High-Level Waste } \\ \text { ICAR } & \text { International Center for Applied Research } \\ \text { IDMS } & \text { Integrated DWPF Melter System } \\ \text { IROD } & \text { Interim Action Record of Decision } \\ \text { IXF } & \text { Ion Exchange Facility } \\ \text { MOU } & \text { Memorandum of Understanding } \\ \text { MPPC } & \text { Multi-Purpose Pilot Plant Campus } \\ \text { MREM } & \text { Millirem } \\ \text { MSL } & \text { Mean Sea Level } \\ \text { NDAA } & \text { National Defense Authorization Act } \\ \text { NEPA } & \text { National Environmental Policy Act } \\ \text { NERP } & \text { National Environmental Research Park } \\ \text { NFPA } & \text { National Fire Protection Association } \\ \text { NPDES } & \text { National Pollutant Discharge Elimination System } \\ \text { NPL } & \text { National Priorities List } \\ \text { OCTF } & \text { Offgas Components Test Facility } \\ \text { ORF } & \text { Organics Removal Facility } \\ \text { OSHA } & \text { Occupational, Safety, and Health Administration } \\ \text { PCB } & \text { Polychlorinated Biphenyl } \\ \text { PCE } & \text { Tetrachloroethylene } \\ \text { PHEF } & \text { Precipitate Hydrolysis Experimental Facility } \\ \text { PWI } & \text { Plutonium Waste Incinerator } \\ \text { R\&D } & \text { Research and Development } \\ \text { RBA } & \text { Radiological Buffer Area } \\ \text { RCRA } & \text { Resource Conservation and Recovery Act } \\ \text { RFI } & \text { RCRA Facility Investigation } \\ \text { RI } & \text { Remedial Investigation } \\ \text { RMA } & \text { Radioactive Material Area } \\ \text { SCDHEC } & \text { South Carolina Department of Health and Environmental Control } \\ \text { SDWA } & \text { Safe Drinking Water Act } \\ \text { SPCCs } & \text { Spill Prevention Control and Countermeasures } \\ \text { SPPP } & \text { Stormwater Pollution Prevention Plan } \\ \text { SRAT/SME } & \text { Slurry Receipt Adjustment Tank/Slurry Mix Evaporator } \\ \text { SREL } & \text { Savannah River Ecology Laboratory } \\ \text { SRI } & \text { U.S. Forest Service Savannah River Natural Resources Management and } \\ & \text { Research Institute } \\ \text { SRS } & \text { Savannah River Site } \\ \text { SRSOC } & \text { Savannah River Site Operations Center } \\ \text { SRTC } & \text { Savannah River Technology Center } \\ \text { STP } & \text { TNX Sanitary Treatment Plant } \\ \text { SVOC } & \text { Semi-Volatile Organic Compound } \\ \text { TCE } & \text { Trichloroethylene } \\ & \end{array}$




\section{List of Acronyms (Cont'd)}

TKN . Total Kjeldahl Nitrogen

TNX

TNX Semi-Works, location of the MPPC

TSCA

Toxic Substances Control Act

TSS

Total Suspended Solids

U IV Uranium IV Facility

USC

Unit Specific Constituents

USEPA

U. S. Environmental Protection Agency

USFWS

U. S. Fish and Wildlife Service

VOC Volatile Organic Compound

WSRC

Westinghouse Savannah River Company 


\subsection{INTRODUCTION}

The Department of Energy (DOE) prepared this environmental assessment (EA) to analyze the potential environmental and safety impacts of DOE planning to allow asset reuse of the TNX Area at the Savannah River Site (SRS) located near Aiken, South Carolina (Figure 1-1). The proposed action would include providing for a location for the Centers of Excellence at or adjacent to SRS and entering into a cooperative agreement with a non-profit management and operations (management firm) contractor to operate and market (as well as sub-lease) the TNX facilities and equipment [32 buildings, trailers, warehouses, etc., within the fenced 5.7 hectare (14 acre) area]. The area (formerly TNX) would be called a Multi-Purpose Pilot Plant Campus (MPPC) and would be used: 1) as location for technology research, development, demonstration, and commercial operations; 2) to establish partnerships with industry to develop applied technologies for commercialization; and 3) serve as administrative headquarters for Centers of Excellence in the program areas of soil remediation, radioecology, groundwater contamination, and municipal solid waste minimization.

The types of activities and businesses envisioned by DOE Savannah River (SR) at the MPPC are: research and development in the areas of environmental remediation, waste management and vitrification of non-radioactive waste, metal fabrication and machining operations, and production of chemicals and polymers. Some pilot-scale manufacturing is expected. DOE-SR expects the campus to be financially self-sufficient within three years.

DOE "embraces privatization as a strategic management tool and will use it where cost-effective and appropriate" (DOE 1997a). Facility reuse would help offset the costs of area support and allow facilities to be available for DOE programs, technology development, and commercialization.

This document was prepared in compliance with the National Environmental Policy Act (NEPA) of 1969, as amended; the requirements of the Council on Environmental Quality Regulations for Implementing NEPA (40 CFR Parts 1500-1508); and the DOE Regulations for Implementing NEPA (10 CFR Part 1021). NEPA requires the assessment of environmental consequences of proposed Federal actions that may affect the quality of the human environment. Based on the potential for impacts described herein, DOE will either publish a Finding of No Significant Impact (FONSI) or prepare an environmental impact statement (EIS).

Recent DOE "Draft Guidance on the NEPA Process in the Privatization Context" (DOE 1997b) states that "DOE increasingly is exploring contracting arrangements that shift greater performance and financial risk of its actions to the private sector. Such "privatization" does not diminish DOE's responsibility under NEPA to consider the environmental impacts of a proposed action before making the decision on the action. Under NEPA, an action is DOE's when it is subject to DOE's control and responsibility, 


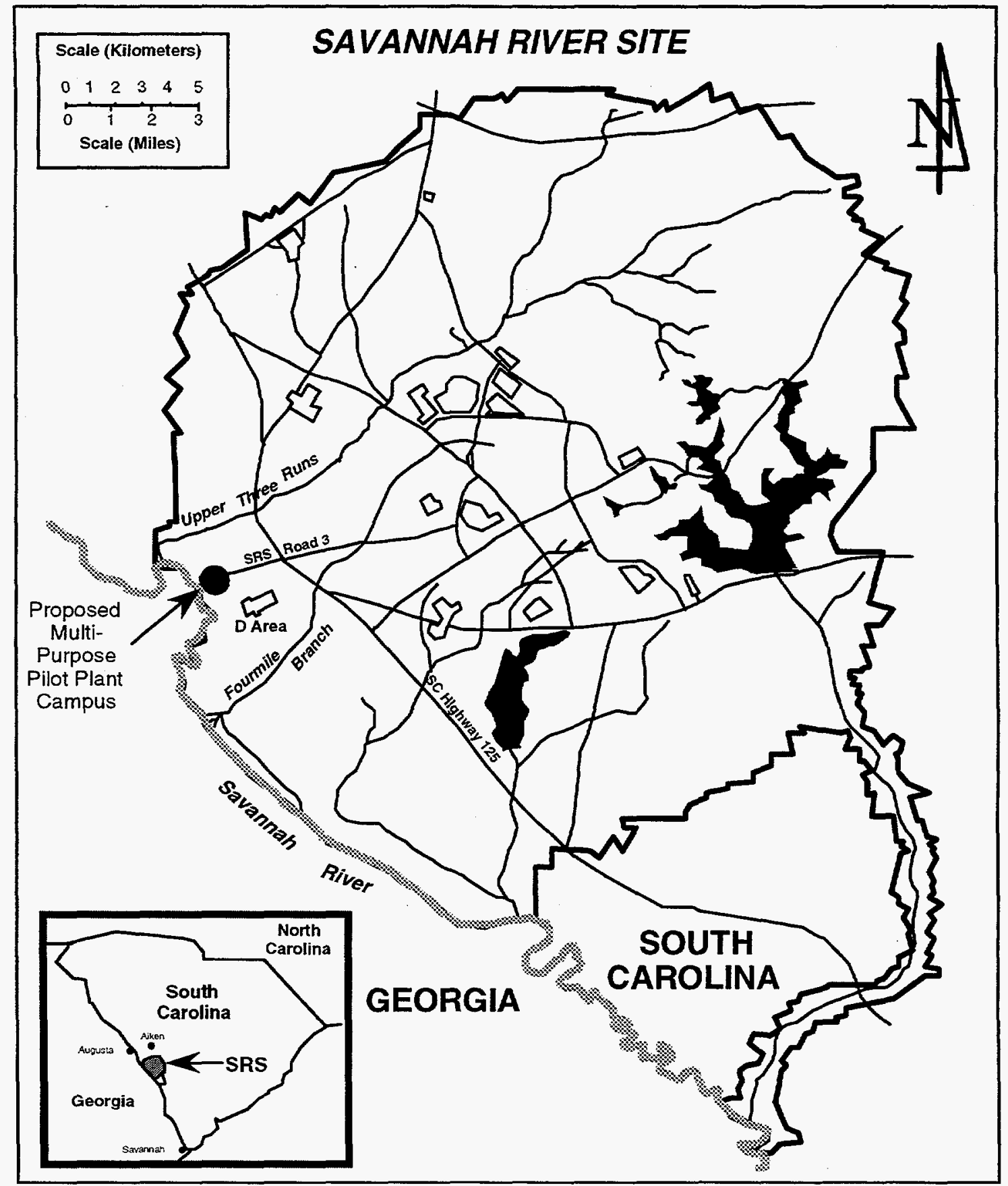

Figure 1-1. Location of the proposed Multi-Purpose Pilot Plant Campus (formerly TNX) at the Savannah River Site, South Carolina. 
regardless of whether Federal or private sector employees perform the work, or whether DOE property would be involved."

\subsection{Background}

\subsubsection{Centers of Excellence}

Congress passed enabling legislation for DOE-SR to establish an International Center for Applied Research (ICAR) in Fiscal Year 1995 (Section 3140 of the Fiscal Year 1995 National Defense Authorization Act). The focus of ICAR included the research and development $(R \& D)$ of any technologies that the Secretary considers appropriate and that are likely to be commercialized. There is a great need for the development, demonstration, and commercialization of the next generation of technologies in the environmental restoration and management mission areas, nuclear and non-nuclear. In order to address the enabling legislation, DOE-SR has established four program areas which will be called Centers of Excellence.

These program areas are soil remediation, groundwater contamination, municipal solid waste minimization, and radioecology (to be located at the Savannah River Ecology Laboratory (SREL) at SRS, but managed from the MPPC). An applied research program would be established in each area which has a coherence of focus and deals quantitatively with the risks associated with the problems to be investigated. R\&D would be conducted mainly by university partnerships, each having an industrial partner to ensure the technical feasibility of developing a technology that can be economically commercialized. A Board of Directors would manage these activities.

The ICAR legislation also states that "The Secretary shall enter into an arrangement to provide for the location of the Center at a suitable facility at, or adjacent to, SRS. The Secretary shall, using competitive procedures, select a nonprofit entity or a group of nonprofit entities to operate the Center. The Center shall promote activities .... in a manner that accomplishes regional development through applied science and technology."

In order to meet these two requirements, DOE-SR plans to set aside the MPPC (formerly known as "TNX") for the location of the Centers of Excellence administrative headquarters, facilities for demonstrations, and the development and nurturing of industrial partnerships.

\subsubsection{TNX Area}

The TNX Area is located 0.8 kilometers (0.5 miles) east of the Savannah River on an upland terrace between Upper Three Runs to the north and Fourmile Branch to the south. The site is at an elevation of 45.7 meters (150 feet) above mean sea level (MSL). Local topography is relatively flat with a slope toward the east away from the Savannah River. A portion of the Savannah River floodplain lies immediately west of the TNX Area at 28.9 meters (95 feet) above MSL. Bottomland hardwoods cover the floodplain terrace; 
the wetlands west of the terrace having stands of cypress (Taxodium distichum) and tupelo (Nyssa spp.) are typical of Savannah River wetlands.

The TNX Area (called TNX Semi-works) was used as a staging area for receipt and testing of large process equipment destined for use in production facilities within SRS. In the early 1950s, it was used to test the Purex process. Since that time, the TNX Area has been utilized primarily as a pilot-scale test facility for the Savannah River Technology Center (SRTC). The most significant pilot-scale testing support has been for high-level waste (HLW) initiatives, particularly that of the Defense Waste Processing Facility (DWPF). Since 1978, the TNX Area has expanded from 3 original buildings constructed in 1950 , to 32 buildings that are currently located within the 5.7 hectare (14 acre) fenced area.

These 32 buildings include administrative offices, process buildings for large-scale experimental demonstrations, laboratories for both research and analytical work, pilot scale facilities, bulk tank storage, industrial wastewater processing facilities and warehouse storage for a wide range of chemical and specialty equipment. Locations of the various buildings within TNX are given in Figure 1-2. These facilities include: 3,716 square meters $(40,000$ square feet) of administrative space; 836 square meters $(9,000$ square feet) of laboratory space; 5,983 square meters (64,400 square feet) of process areas; and 2,230 square meters (24,000 square feet) of warehouse space. There is an adequate infrastructure (water, sewer, electric, steam, and compressed air) to perform a multitude of activities. Currently the TNX Area is used primarily for Defense Waste, Interim Waste and Environmental Sciences programs conducted by SRTC. In addition, the facility hosts other programs which are sponsored by DOE-SR, SRTC, and the Westinghouse Savannah River Company (WSRC) Community Outreach Division. The TNX Area also supports technology transfer initiatives through Cooperative Research and Development Agreements (CRADAs) with private industry. These existing, funded activities will continue to operate at the TNX Area under WSRC, or successor, as a sub-lessee to the management firm. A current aerial photograph, Figure 1-3, shows the TNX Area as it appears today.

Several facilities located adjacent to the TNX Area are outside the fenced area and are therefore not part of the scope being evaluated within this EA. These are an abandoned sanitary sewer tile field to the south, the New TNX Seepage Basin to the east, the Kaolin Settling Basin to the north, the Old TNX Seepage Basin Discharge Gully, Outfall Delta, and TNX wetlands to the west (see WSRC 1997 for detailed figures). The TNX Sanitary Treatment Plant (STP) and TNX Effluent Treatment Plant (ETP) are separately fenced and considered to be part of the TNX Area.

\subsubsection{Operational Facilities}

The major buildings and facilities located at the TNX Area, with their past and current use are outlined below. The management firm would be responsible for management of these available facilities. 


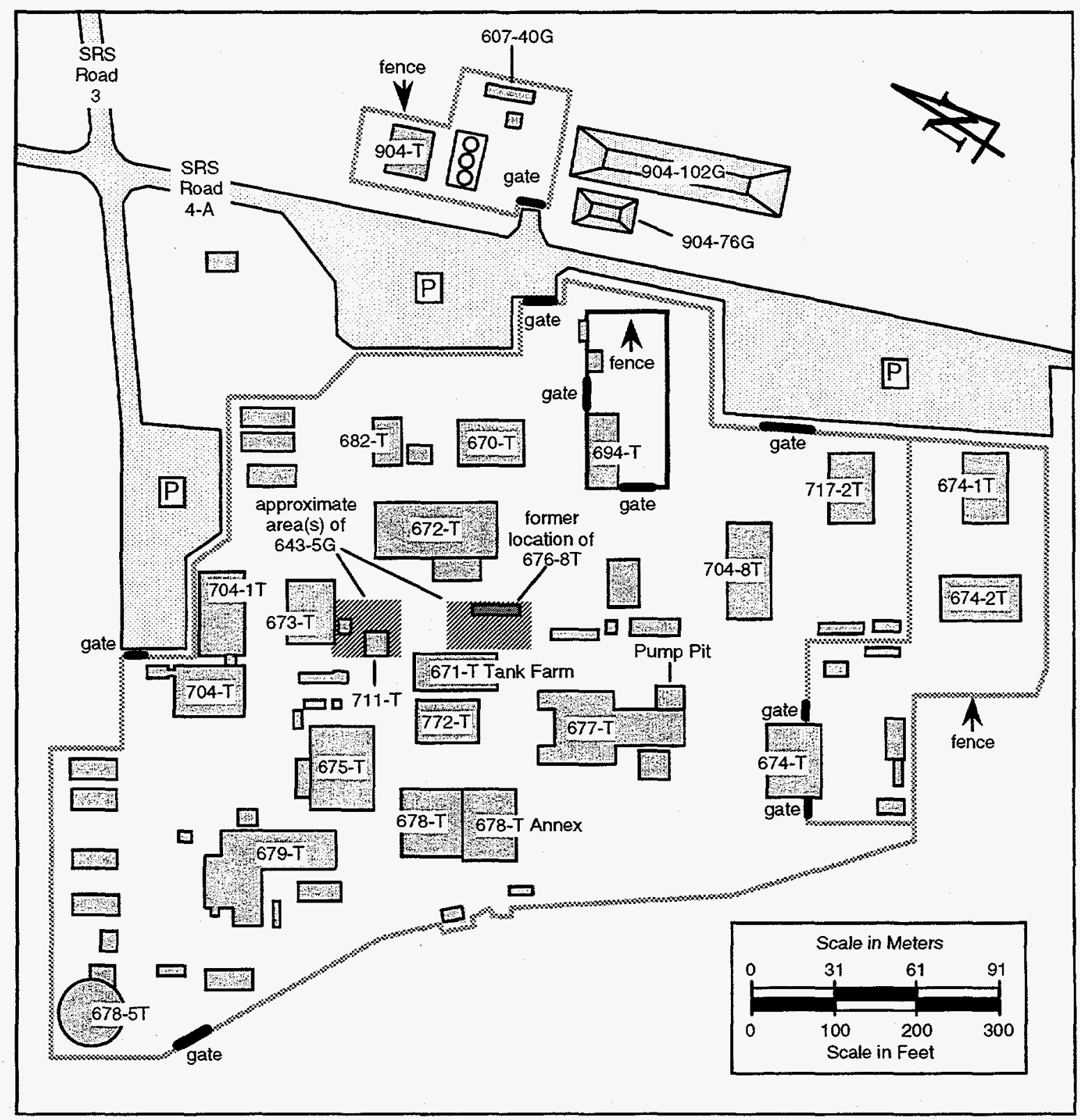

Figure 1-2. TNX Area: Location of Buildings and Facilities Identified in this EA. 


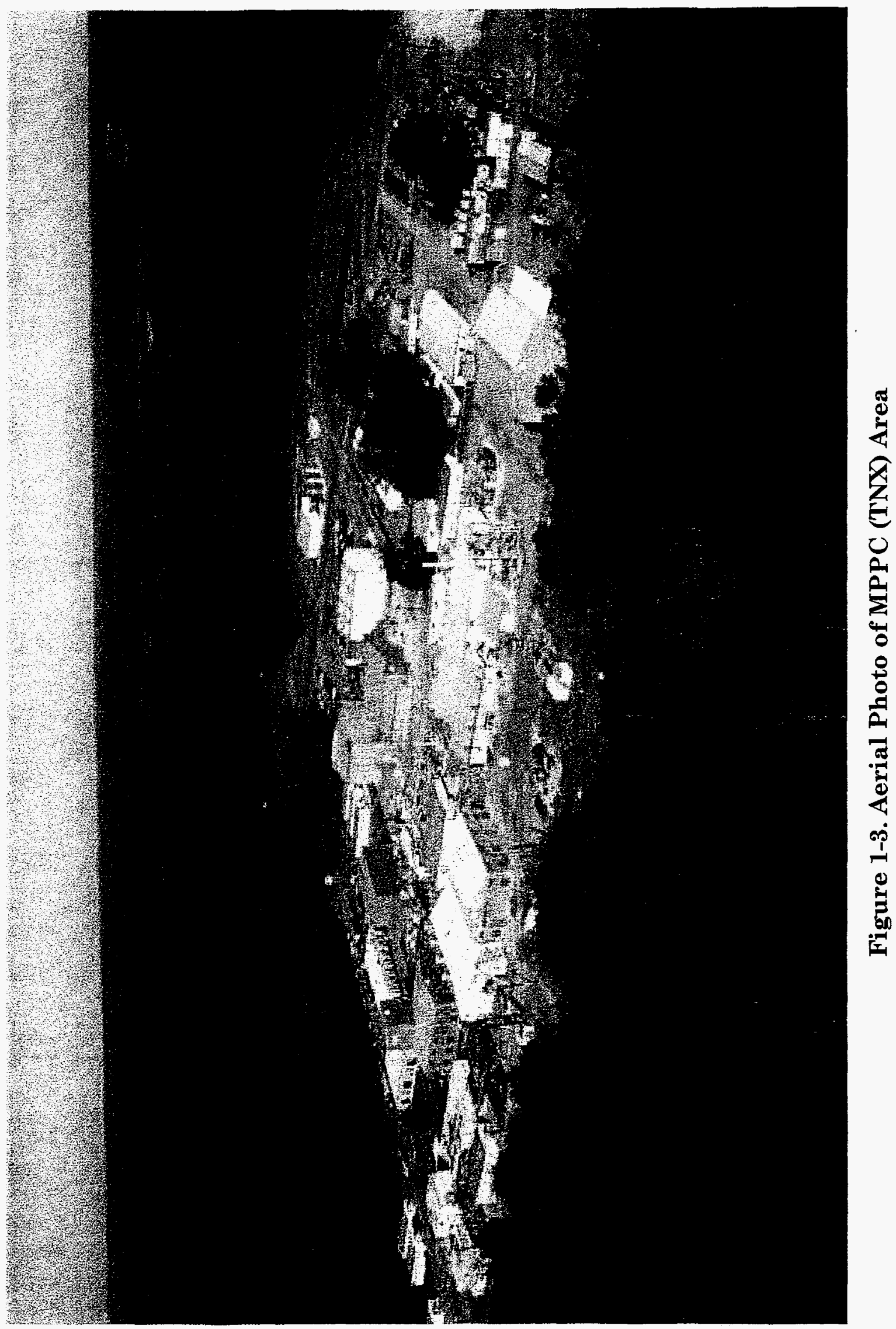


Building 670-T, constructed in 1985, houses a robotics demonstration facility. Existing equipment in Building 670-T includes a large shredder, telerobot, and bagless transfer system.

Building 671-T, constructed in 1980, consists of a tank farm with three 7,560 liter $(2,000$ gallon) tanks and five 37,800 liter (10,000 gallon) tanks. This tank farm has supported facilities in Buildings 672-T, 675-T, 678-T and 682-T, as well as received material from the Slurry Receipt Tank located adjacent to the slurry unloading dock. Materials traditionally held in these tanks include simulated sludges, slurries, and raw chemicals. All tanks in this operational facility are expected to be empty at the time of lease inception.

Building $672-\mathrm{T}$, constructed in 1983 , consists of a chemical processing facility, an electrical and instrumentation shop, and a control room. The chemical processing facility currently contains the Integrated DWPF Melter System, the Slurry Receipt Adjustment Tank/Slurry Mix Evaporator (SRAT/SME), the Ion Exchange Facility (IXF), and the Americium/Curium $(\mathrm{Am} / \mathrm{Cm})$ Melter.

Building 673-T, constructed in 1979, is a chemical processing facility and administrative office. Existing equipment in Building 673-T includes the canister bandsaw and the Delphi Detoxification (DETOX) process being operated under a CRADA. Historically, this facility was the site of the large-scale upset canister welder demonstration unit, and housed a metallurgical laboratory.

Building 674-T, constructed in 1983, is a raw materials storage facility with one office. It is currently used to store raw materials supporting active programs at the TNX Area.

Building 674-1T, constructed in 1992, is a storage facility. It is currently used to store drums of legacy materials, but is expected to be empty at the time of lease.

Building $674-2 T$, constructed in 1992 , is a storage facility. It is currently used to store glass canisters from DWPF cold runs. Building 675-T, constructed in 1979 is a chemical processing facility and control room. Existing equipment in Building 675-T is limited to a skid-mounted ion exchange system, which is inactive. Historically, this facility was the site of several large-scale melter development and demonstration projects.

Building 677-T, constructed in 1950, consists of a maintenance shop, a laboratory where small-scale demonstration projects were operated, a bioremediation laboratory, and a bay area where larger-scale pilot projects were demonstrated. Existing equipment in Building 677-T includes the Plutonium Waste Incinerator (PWI) and Mobile Offgas System, the Uranium IV (U IV) facility, the Geometrically Favorable Dissolver, and the Centrifugal Contactor. Equipment and surrounding facilities housing the Geometrically Favorable Dissolver and the Centrifugal Contactor are radioactively contaminated. The U IV facility has a process history of radioactive work, but is not contaminated. Historically, 
this facility contained a Crossflow Filter Facility, formerly located where the PWI is now, and associated equipment in a pump pit outside the southeast corner of the building.

Building 678-T, constructed in 1950, and the 678-T Annex, constructed in 1979, is a chemical processing facility and supporting laboratory. Existing inactive equipment in Building 678-T includes the Offgas Components Test Facility, the Mott Filter Test Stand, and a tank farm. Historically, the tank farm in this facility was used to store raw material feed makeup for the Precipitate Hydrolysis Experimental Facility (PHEF), for development of melter feed, and for storage of aluminum nitrate for calibration of separations frames columns. Building 678-T was the former site of an evaporator which exploded in 1953. Building 678-T is currently the site of an apparatus operated by Ener Tech under a CRADA. The tank farm, the former site of the evaporator, the laboratory, and a concrete pad outside of the west wall of Building 678-T are radioactively contaminated.

Building $678-5$ T, constructed in 1979 , is the full-scale tank mockup. This facility has historically been used for pump studies as well as testing high-level waste-tank pumps. It is currently being used for testing of waste-tank pumps.

Building 679-T, constructed in 1950, consists of two laboratories and administrative office space. Historically, this facility contained various laboratories and a process area which was renovated into office space in 1985. The process area previously held equipment supporting reactor cooling studies. The clear well, a below-grade holding tank fed by two artesian wells in the TNX Area and used as a holding tank for process and fire water, is located on the north end of 679-T.

Building 682-T, constructed in 1985, is the PHEF, a pilot scale demonstration facility. The facility was operated until 1994.

Building 694-T, constructed in 1986, is a storage building. Historically, this facility was used as a construction fabrication shop. The facility and adjacent laydown areas are currently used for storage in support of the Environmental Sciences programs at the TNX Area.

Buildings 704-T, constructed in 1983, and 704-1T, constructed in 1986, are and always have been used as administrative buildings.

Building 704-8T, constructed in 1989, houses administrative facilities for the Environmental Sciences programs.

Building $717-2 T$, constructed in 1988 , formerly housed a construction fabrication shop.

Building 772-T, constructed in 1986, houses an analytical laboratory which provides area-wide analytical support. 
The TNX Area has a handling facility located north of Building 675-T, where raw materials such as simulated sludge were off-loaded for experimental use. An aboveground 18,900 liter (5,000 gallon) Slurry Receipt tank is located adjacent to this unloading station where simulated sludge was off-loaded. A second station is located south of Building 677-T where uranyl nitrate solutions were loaded/unloaded for transportation at the TNX Area.

Two other operational facilities are considered to be part of the TNX Area, although they are fenced separately in an area adjacent to the main fenced area. They include the following:

- Building 904-T, the TNX Effluent Treatment Plant, constructed in 1987, which currently treats all process effluents from the TNX Area.

- Building 607-40G, the TNX Sanitary Treatment Plant, constructed in 1985 , which currently treats all sanitary waste from the TNX Area.

\subsubsection{Excluded Facilities}

Within the boundaries of the TNX Area, excluded facilities that will not be the responsibility of the management firm are outlined below:

Two underground storage tanks have been removed from service at the TNX Area. These include tank D-23, a 6,804 liter (1,800 gallon) tank located east of Building 678-T (used primarily for raw materials, i.e. oxalic acid), and J Tank, a 7,560 liter (2,000 gallon) tank located at the 671-T Tank Farm (used primarily for makeup of sodium hydroxide). Both tanks were emptied of their contents, cleaned, filled with sand, and had inlet and outlets capped in 1982.

The TNX Burying Ground, 643-5G, was located in three known and two suspected areas within the TNX Area fence. This area was used to bury the remains of a 1953 accidental explosion of an experimental evaporator which contained 590 kilograms ( 0.6 tons) of uranyl nitrate. Approximately 95 percent of this material has been removed to date. This facility is currently being evaluated in the environmental restoration program. Additional detail relative to the characterization of this facility is provided in the RCRA Facility Investigation (RFI)/Remedial Investigation (RI) Report with Baseline Risk Assessment (BRA) for the TNX Area Operable Unit [see WSRC (1997) for details].

The Old TNX Seepage Basin, 904-76G, was in operation from 1951 through 1980 . This facility was used to collect process wastewater, allowing settling of sediments in the small inlet basin and filtration through natural ion exchange media in the larger basin. This facility was replaced by the New TNX Seepage Basin (904-102G) and is currently being evaluated in the environmental restoration program. The facility is radiologically contaminated and contains heavy metals. The most recent groundwater data indicate that no primary drinking water standard maximum contaminant levels for monitored 
parameters have been exceeded. Therefore, a closure remedy of No Waste Removal and Backfilling with Natural Soil has been selected. Additional detail relative to the characterization of this facility is provided in WSRC (1997).

\subsection{Purpose and Need for Action}

DOE is charged with implementing Section 3140 of the Fiscal Year 1995 Defense Authorization Act by providing suitable facilities to establish an ICAR at or adjacent to SRS with the intent to reuse site assets. The enabling legislation provides DOE an opportunity to select a non-profit entity to operate the Center. To meet the legislative intent, DOE-SR is planning to contract with a non-profit management firm to serve as a management firm to lease facilities for $R \& D$ in the areas of environmental remediation, waste management and vitrification of non-radiological waste, metal fabrication and machine operations, and production of chemicals and polymers. Recent ICAR legislation focuses on R\&D of any technologies that the DOE Secretary considers appropriate and that are likely to be commercialized. There is a need for the development, demonstration, and commercialization of the next generation of environmental restoration and management technologies. Some pilot-scale manufacturing is expected. DOE-SR expects the campus to be financially self-sufficient within three years.

PROPOSED ACTION AND ALTERNATIVES

\subsection{Proposed Action}

The proposed action is for DOE-SR to contract with a non-profit entity (management firm) to serve as a management firm to administer, operate, and market (as well as sub-lease) the TNX facilities and equipment [including 32 buildings, trailers, warehouses, etc., within 5.7 hectares (14 acres)]. The area would be: 1) used as a location for technology research, development, demonstration, and commercial operations; 2) used to establish partnerships with industry to develop applied technologies for commercialization; and 3) establish and operate Centers of Excellence in the program areas of soil remediation, groundwater contamination, municipal solid waste minimization, and radioecology (to be located elsewhere on SRS and not part of this action except for administrative functions). The location of the various facilities are shown in Figure 1.2.

DOE-SR plans to encourage the submission of cooperative agreement applications with non-profit entities wishing to manage and operate, as well as propose sub-leases for the MPPC facility. The potential management firm would be responsible for determining and implementing the strategy for executing a program whose objectives include the administration and operation of the facilities (current annual operational cost approximately $\$ 3$ million) and equipment at the MPPC. The management firm would not be responsible for remediation, environmental restoration, surveillance, and maintenance costs associated with legacy hazardous or radioactive materials at the facility. The 
management firm would be responsible for any new contamination. Any non-legacy contamination (hazardous and non-hazardous) that results from the management firm's operations (as well as a sub-lessee) would be the responsibility of the management firm, not DOE-SR. DOE-SR anticipates that the management firm would attain self-sufficiency within three years. The proposed action would also allow DOE-SR to meet its objective of preserving the TNX Area for future site support missions.

\subsubsection{Management Firm Responsibilities}

DOE-SR plans for the management firm of the MPPC to be responsible for operating, maintaining, and providing technical support required to perform technology research, development, demonstration, and commercial operations. Currently, the campus is used primarily for Defense Waste, Waste Management, and Environmental Sciences programs conducted by SRTC. In addition, the facility presently hosts work for others/users facility programs which are sponsored by DOE-SR, SRTC, and WSRC Community Outreach Division. The campus also supports technology transfer initiatives through CRADAs with private industry. These existing, funded activities would continue to operate at the MPPC under WSRC, or successor, as a sub-lessee to the management firm.

To support these programs, DOE-SR plans to have the management firm operate and maintain the infrastructure (steam and process water) to remain in compliance with current air and NPDES permits. General maintenance of 32 administrative buildings, trailers, warehouses and major structures, (i.e., roofs, grounds/roads) would be performed by the management firm. The management firm would support various $R \& D$ activities by providing facility space, available equipment and supplies (pumps, tanks, instrumentation, etc.), technical support, operations and maintenance. The management firm would ensure that lessees of facilities comply with requirements of the Occupational, Safety, and Health Administration (OSHA), National Fire Protection Association (NFPA) 101 Life Safety Codes, Emergency Management Directives, and all environmental, safety, and health laws and regulations.

\subsubsection{Centers of Excellence}

DOE-SR plans to provide office space (no less than two offices) and a conference room for the Board of Directors and the staff of the Centers of Excellence at the MPPC. The major link to four of the Centers of Excellence (soil remediation, groundwater contamination, radioecology, and municipal solid waste minimization) would be through the development and demonstration of technologies. The management firm's role would be to identify additional commercial partners to either assist in the commercialization of technologies or advise the Board of Directors in pursuit of other innovative and needed solutions. The management firm would manage the technologies selected for demonstration and would not be responsible for clean up of the existing legacy materials in the TNX Area. Any processes found by the management firm to be utilized in the clean up of TNX would require DOE-SR and regulatory approval. 


\subsection{Alternatives to the Proposed Action}

In accordance with NEPA regulations, DOE-SR examined the following alternatives to the proposed action:

- No action, not privatize and not establish the Centers of Excellence at TNX

- Establish the Centers of Excellence at other DOE-SR facilities

- $\quad$ Support similar ICAR efforts offsite within the five-county area

\subsubsection{No Action, Not Privatize and Not Establish the Centers of Excellence at TNX}

One alternative to the proposed action is to take no action. This would consist of DOE-SR not carrying out a priority privatization mission under the ICAR legislative mandate and funding made available by the Congress to establish partnerships for environmental technology commercialization development at a location which could provide significant infrastructure for the Centers of Excellence. If DOE-SR chooses this alternative, the impacts described in Section 4 would not occur. This alternative would not enable DOE-SR to preserve the TNX Area for future SRS support missions as the facilities would remain underutilized and not cost effective. The "Transition" Plan (Hayford and Bokesch 1997) would be implemented to eventually deactivate the facilities.

\subsubsection{Establish the Centers of Excellence at Other DOE-SR Facilities}

Another alternative would be to implement the proposed action at a different location on SRS. Areas such as $M$ Area or the reactor areas were possible candidates as they have been preliminarily evaluated by DOE-SR for limited asset reuse. These areas do not provide ready access for commercial activities, contain additional contamination, and lack the necessary infrastructure such as the administrative office space, laboratory facilities, process water, and segregated sanitary and waste facilities. These areas are not near a major public access making materials transportation more difficult and are not close to the Three Rivers Solid Waste Authority Regional Landfill, located near TNX on SC Route 125, where the coordination and management of municipal solid waste technology development and commercialization is expected to occur (DOE 1995). Environmental Baseline Surveys (EBSs) may be required for leasing of DOE-SR property and have not been initiated for these areas.

\subsubsection{Support Similar ICAR Efforts Offsite Within the Five-County Area}

Another alternative would be to implement the proposed action at other offsite locations within the five-county area (Columbia, Richmond, Aiken, Allendale, and Barnwell Counties). The implementation of this alternative would not allow direct study of in situ 
site contamination and the development of site-specific cleanup technologies to bring to commercialization. Also, there are not enough funds provided in the ICAR legislation budget to fund new facilities either on or offsite. There are also insufficient laboratory facilities within the five-county area to support the project and needed access to cleanup technologies being developed and obtaining materials for research located at the Three Rivers Solid Waste Authority Regional Landfill would be more difficult if the Centers were located away from SRS.

\subsection{AFFECTED ENVIRONMENT}

\subsection{Site Conditions}

\subsubsection{Land Use}

SRS occupies an area of approximately 800 square kilometers (300 square miles) in southwestern South Carolina (Figure 1-1). The site borders the Savannah River for about 27 kilometers (17 miles) near Augusta, Georgia, and Aiken and Barnwell, South Carolina. SRS contains five nuclear production reactor areas, two chemical separations facilities, waste treatment, storage and disposal facilities, and various supporting facilities. The Final EIS for the shutdown of the River Water System at SRS (DOE $1997 \mathrm{c}$ ) and the most recent socio-economic survey of the six-county SRS area of influence (HNUS 1997) contain additional information on SRS areas and facilities, and the areas surrounding SRS.

\subsubsection{Meteorology and Climatology}

The SRS region has a temperate climate with mild winters and long summers. The average annual rainfall at SRS is about 122 centimeters (48 inches) and the average wind speed in 1987-91 was 13.7 kilometers/hour (8.5 miles/hour) (Bauer et al. 1989; DOE 1995). Tornadoes have been observed during every month of the year in the area encompassing SRS, but occur most frequently in the spring (Bauer et al. 1989). Only a few instances of slight to moderate tornado damage to support facilities have been documented for the site to date. Bauer et al. (1989) contains additional information on SRS meteorology and climatology. The general meteorological and climatological data for SRS would be representative of that for the MPPC location.

\subsubsection{Geology and Seismology}

SRS is located in the Aiken Plateau physiographic region of the upper Atlantic Coastal Plain approximately 40 kilometers ( 25 miles) southeast of the Fall Line which separates the Piedmont Plateau from the Atlantic Coastal Plain. The topographic surface of the coastal plain slopes gently seaward and has under it a wedge of seaward-dipping unconsolidated and semi-consolidated sediments from the Fall Line to the coast of South Carolina. The Atlantic Coastal Plain tectonic province, in which SRS is located, is 
characterized by generally low seismic activity that is expected to remain subdued (Haselow et al. 1989).

No significant faults are located within the MPPC area. The most active seismic zones in the southeastern United States are all located over 160 kilometers (100 miles) away from the site. A recent EIS (DOE 1997c) contains information on SRS fault location and earthquake occurrences.

\subsubsection{Hydrology}

The Savannah River forms the western boundary of SRS and receives drainage from five major tributaries on the site: Upper Three Runs, Fourmile Branch, Pen Branch, Steel Creek, and Lower Three Runs. These tributaries receive varying types of wastewater discharges from plant processes and sanitary treatment systems, all of which are permitted through the National Pollutant Discharge Elimination System (NPDES). On SRS, various plant processes also require the pumping of Savannah River water and/or onsite groundwater. A recent EIS (DOE 1997c) contains information on groundwater systems on SRS and in the surrounding region.

\subsubsection{Ecological and Cultural Resources}

Since 1951, when the U.S. Government acquired SRS, natural resource management practices and natural succession outside of the construction and operation areas at SRS have resulted in increased ecological complexity and diversity of the site. Forested areas support a diversity of wildlife habitats that are restricted from public use. Forest management practices include controlled burning, harvesting of mature trees, and reforesting. Wildlife management includes control of white-tailed deer (Odocoileus virginianus) and wild swine (Sus scrofa) populations through supervised hunts. SRS, which was designated as the first National Environmental Research Park (NERP) in 1972, is one of the most extensively-studied environments in this country. Wike et al. (1994) contains additional information on the biotic characteristics of SRS.

Six species on SRS are afforded protection by the Federal Government under the Endangered Species Act of 1973. These are the bald eagle (Haliaeetus leucocephalus), wood stork (Mycteria Americana), red-cockaded woodpecker (Picoides borealis), American alligator (Alligator mississippiensis), shortnose sturgeon (Acipenser brevirostrum), and smooth purple coneflower (Echinacea laevigata). None of these species are known to occur on or near the proposed MPPC at TNX (LeMaster 1997).

A number of wildlife species are present in and around the general area of the project location. The species composition is comparable to similar habitat types elsewhere on SRS. Comprehensive listings of wildlife species can be found in Wike et al. (1994) and Mayer and Wike (1997) which specifically lists wildlife species found in the TNX Area. 
Cultural resources at SRS are managed under the terms of a Programmatic Memorandum of Agreement among DOE-SR, the South Carolina State Historic Preservation Officer, and the Advisory Council on Historic Preservation. DOE-SR uses this Programmatic Memorandum of Agreement to identify cultural resources, assess these in terms of National Register eligibility, and develop mitigation plans for affected resources in consultation with the South Carolina State Historic Preservation Officer. DOE-SR would comply with the stipulations of the Programmatic Memorandum of Agreement for all activities related to the proposed MPPC.

\subsubsection{Radiation Environment}

A person residing in the Central Savannah River Area (within 80 kilometers or 50 miles of SRS) received an average annual radiation dose of about $360 \mathrm{mrem}$; SRS contributes less than 0.1 percent of that total. Natural radiation sources contribute about $300 \mathrm{mrem}$, medical exposures contribute about $53 \mathrm{mrem}$, and consumer products contribute about 10 mrem. The most recent SRS annual environmental report (Arnett and Mamatey 1997) contains more information on the radiation environment.

\subsection{TNX Conditions}

An EBS (WSRC 1997) was performed to support the lease of the TNX Area facilities by DOE-SR. The survey encompasses all facilities within the boundaries of the TNX Area fence as well as facilities and property located directly adjacent to, but outside the property fence. The EBS was prepared to be consistent with the requirements of the Community Environmental Response Facilitation Act (CERFA) of 1992 and the National Defense Authorization Act (NDAA) of 1994. DOE-SR plans to use the EBS to demonstrate to Region IV USEPA and SCDHEC that the TNX Area is suitable for lease with selected DOE control.

This section summarizes information from the EBS and the status of various facilities and their environmental permits at TNX. This establishes the baseline conditions and permitting status of existing TNX operations which the management firm would become responsible for, except the clean up required under the FFA.

\subsubsection{Air Quality}

Historically, TNX Area emissions have included those from small to large-scale pilot plant processes and laboratory hoods.

There are three permitted emission points at the TNX Area. These are permitted by the SCDHEC Bureau of Air Quality Control in the SRS Air Quality Operating Permit. The current permit was issued on February 1, 1994, revised on August 1, 1994, and has an expiration date of February 1999. 
An air emissions inventory was conducted in 1991, which identified all discharges at SRS, including the TNX Area and adjacent facilities.

The TNX groundwater air stripper system and airlift recirculation well are exempted from Air Quality Control permits since it has been demonstrated that all uncontrolled air emissions from the remediation systems will be well below any regulatory trigger levels.

Air emissions are reported on an annual basis in order to maintain compliance with the requirements of the Emergency Planning and Community Right to Know Act (EPCRA). No releases from the TNX Area were experienced in 1996.

\subsubsection{Water Quality}

\subsubsection{Domestic Water}

Domestic potable water for the TNX Area is provided from D-Area Domestic Water facilities. Two artesian wells that formerly provided domestic water to this area are now utilized as fire water and process nonpotable water sources.

\subsubsection{Fire Water}

Fire water to the TNX Area is provided by two artesian wells located at TNX. Fire water is stored in a clear well located on the north end of Building 679-T. Historical conditions at the TNX Area (i.e. nature of processes, number and location of personnel) have not required that sprinkler systems be in place in the area to maintain compliance with Life Safety Codes of NFPA standards. As a result, DOE-SR has not required that existing fire pumps be upgraded to NFPA 20 code for property protection. In the event that new processes or personnel changes required sprinkler systems based on NFPA Life Safety Codes, an upgrade of the fire pumps would also be required.

\subsubsection{Stormwater}

SRS is currently operating under two NPDES permits. The industrial wastewater permit (SC0000175) was issued in October 1996. The site also has a general stormwater permit (SCR000000) that contains outfalls that discharge only stormwater.

The site Stormwater Permit requires the preparation of a Stormwater Pollution Prevention Plan (SPPP). In the TNX Area, only outfalls X-01, X-05, X-07 and X-17 are included in the SPPP. The SPPP is currently being revised to include outfall $X-11$. Outfalls $X-8 D$, $\mathrm{X}-09, \mathrm{X}-10$, and $\mathrm{X}-18$ are not included in the SPPP, and therefore, not permitted because they originate from administrative areas.

In addition, stormwater is routed to outfalls X-04 and X-08; however, these are combined with industrial discharges and permitted under the TNX Area NPDES industrial wastewater permit. 
Representative samples at stormwater outfall X-01 at the TNX Area are routinely analyzed for Biological Oxygen Demand (BOD), Total Suspended Solids (TSS), oil and grease, phenol, Chemical Oxygen Demand (COD), Total Kjeidahl Nitrogen (TKN), NO2, NO3, PO4, TOX, cadmium, chromium, copper, mercury, benzene, $\mathrm{pH}$ and temperature and reported to SCDHEC.

\subsubsection{Surface Water Quality}

The SRS NPDES permit No. SC0000175 requires the development of a Spill Prevention Control and Countermeasures (SPCCs) Plan for petroleum products and a Best Management Practices (BMPs) Plan for other chemicals. These plans include a listing of storage tanks, containers, transformers and their locations, usage of chemicals, and risks and consequences of spills of the material along with the flow patterns the materials would follow in the event of a release.

\subsubsection{Process Water}

Process water is provided from two artesian wells located at the TNX Area.

From 1951 until 1987, wastewater generated within the TNX Area was discharged to unlined basins through a network of underground process sewers. Beginning in 1987, process waters were discharged to the TNX Effluent Treatment Plant (ETP) for treatment prior to discharge to the Savannah River through NPDES outfall X-08.

The SRS NPDES industrial wastewater permit (SC0000175) was issued in October 1996. There are five industrial outfalls that discharge from the TNX Area facilities, and all are permitted.

All of the aforementioned outfalls (with the exception of outfall X-8B) are sampled for effluent characteristics, including flow, total suspended solids and $\mathrm{pH}$, on a routine basis. In addition, outfall $\mathrm{X}-8 \mathrm{~A}$ is sampled for $\mathrm{BOD}$, fecal coliform and dissolved oxygen; outfall $\mathrm{X}-8 \mathrm{~B}$ is sampled for $\mathrm{BOD}$, total organic carbon, mercury, benzene, and phenol. Outfall $\mathrm{X}-8 \mathrm{C}$ is sampled for flow, trichloroethylene (TCE) and tetrachloroethylene (PCE) only.

\subsubsection{Industrial Wastewater}

Five facilities located at the TNX Area are operated under industrial wastewater permits. These include the TNX ETP, the Ion Exchange Facility, the Organic Removal Facility (ORF), the Groundwater Air Stripper, and Mobile Trickle Flow Bioreactor System.

The TNX ETP processes all industrial wastewater prior to discharge to the Savannah River via outfall X-08. The facility consists of three 151,400 liters (40,000 gallon) collection tanks. Filtration systems and a filter press remove and dewater solids. 
The Ion Exchange Facility, located in Building 672-T was designed to remove mercury from liquid effluents generated in the Integrated DWPF Melter Systems (IDMSs) facility. The facility consists of feed and product tanks, and ion exchange columns. This facility is operational.

The Organic Removal Facility consists of two activated carbon columns, connected in series and is designed to remove organic contaminants from liquid effluents generated during melter research projects in Building 672-T and 682-T. This facility is operational.

The Groundwater Air Stripper System consists of four production wells and a stripper unit, designed to remove organic contamination from TNX groundwater. The facility is operational.

The Mobile Trickle Flow Bioreactor System is a mobile experimental treatment facility. This unit treated groundwater from a monitoring well at TNX. The system reduced concentrations over 95 percent during operation in 1994 and 1995. This unit and its performance will be used as a basis for comparison between the expanded bed bioreactor design and trickling filter bioreactor design. Once this comparison is made, design and construction of a full-scale treatment system may be investigated by the management firm. This system is inactive.

Industrial Wastewater permits for the Fluidized Bed Reactor and the TNX Area GeoSiphon Cell have been issued by SCDHEC for demonstration use. SRS currently has an application with SCDHEC to establish a discharge directly into the Savannah River. The discharge has been designated as X-19. The permit application is anticipated for early 1998.

All effluents from the above facilities are controlled per the NPDES process via discharge permits.

\subsubsection{Sanitary Wastewater}

Domestic sanitary sewage from all TNX Area buildings is processed through the TNX STP. The STP is a package treatment plant, utilizing industry standard technology. This treatment plant has been operational since June 1986. Ultraviolet disinfection is used to kill bacteria in the treated wastewater. This treatment plant discharges to outfall X-08 through sampling point X-8A.

\subsubsection{Groundwater}

The Water Table Aquifer is about 16.2 meters (50 feet) below the ground surface within the fenced area of TNX and about 7.6 meters ( 25 feet) below ground surface throughout much of the TNX Area Operable Unit (area being investigated for possible remediation under CERCLA) outside the fenced area. The Water Table Aquifer outcrops in the TNX 
wetlands. The Gordon Aquifer is a semi-confined aquifer beneath the TNX Area Operable Unit.

There are a total of more than 50 groundwater monitoring wells, soil borings, and piezmeters located at or adjacent to the TNX Area, the first series of wells having been installed in 1980. Each well series is designed to provide specific information related to a waste unit or to provide general area information.

Most monitoring wells are sampled and analyzed quarterly for a wide range of parameters, including indicators of water quality and specific chemical and radiological constituents.

The TNX groundwater has been found to be contaminated with chlorinated Volatile Organic Compounds (VOCs), primarily TCE, and to a lesser extent PCE, and carbon tetrachloride. The VOC plume underlies 3.2 hectares ( 8 acres) and has a maximum thickness of 6.1 meters (20 feet) [see WSRC (1997) for details]. Groundwater characterization activities indicate that contamination is limited to the shallow water table aquifer, and the contaminant plume is spreading into the TNX wetlands, before it reaches the Savannah River. No contamination emanating from the facility has been detected in the river.

An RFI/RI and BRA have been conducted for the TNX Groundwater Operable Unit (GWOU). A report summarizing the findings and conclusions from this investigation and analysis was recently published. Results extracted from this report are summarized in Appendix 1 of WSRC (1997).

An Interim Action Record of Decision (IROD) for the TNX GWOU was authorized by USEPA, SCDHEC, and DOE on November 16, 1994. The IROD mandated that an interim remedial action be initiated within 15 months of signing of the IROD. The objectives of the interim action are to:

- Reduce potential risk to human health and the environment

- Maintain risk at acceptable levels to the onsite worker at the seepline

- Remove VOC contamination in the groundwater near the plume core

- Stabilize the plume by inhibiting migration of elevated levels of VOCs (500 ppb TCE) to the swamp

- Prevent further aquifer degradation

The selected remedy for accomplishing the Interim Remedial Action goals was designated the Hybrid Groundwater Corrective Action (HGCA) system. The HGCA was composed of two components: 1) traditional pump and treat technology to treat and inhibit further migration of the $500 \mathrm{ppb}$ dissolved VOC plume, and 2) an innovative in-situ technology, called an airlift recirculation well, located at the heart of the plume to expedite remediation. Testing completed in September 1996 determined that the recirculation well was not effective in removing contaminants at this location due to 
site-specific conditions, and further operation of the recirculation well at the TNX Area was discontinued. It was also determined that the pump and treat (air stripper) system would adequately meet the remedial objectives of the IROD. The air stripper system began operations September 16, 1996. The projected life of this facility is 15 years. The air stripper system operates under an Industrial Wastewater Treatment Facility permit (number 17938-IW) and discharges to outfall number X-08, NPDES permit number SC0000175.

\subsubsection{Waste Cleanup}

SRS was placed on the USEPA National Priorities List in 1989. As a result, DOE was required to identify all waste units and to enter into a Federal Facility Agreement (FFA) that establishes cleanup goals and time tables with USEPA and SCDHEC. SRS has combined the RFI and CERCLA RI processes for simplicity, to avoid duplication of effort, and reduce costs.

\subsubsection{RCRA/CERCLA Units}

There are four RCRA/CERCLA units associated with the TNX Area and surrounding facilities. They are:

Old TNX Seepage Basin, 904-76G

New TNX Seepage Basin, 904-102G

TNX Burying Ground, 643-5G

TNX Groundwater

These facilities are collectively identified as the TNX Operable unit.

The Old TNX Seepage Basin, located on the west side of the TNX Area, was an unlined excavation designed to remove solids from wastewater and contain it until it could seep into the underlying sediments that were believed to act as natural ion exchange media. A 0.85 centimeter $(6$ inch) pipe connected the inlet section of the basin to the seepage section and a similar sized pipe was used to direct overflow into the adjacent floodplain during periods of unusually high flow to the basin. The basin was constructed in 1958 and received laboratory wastes until 1980 when it was replaced by the New TNX Seepage Basin. The Old TNX Seepage Basin received a diverse suite of chemical constituents that ranged from inorganic salts and low-level radionuclide discharges to organic solvents. In 1981 , the west wall of the basin was breached to drain the impounded liquids to nearby swamplands; the basin was backfilled with a sand and clay mixture and the top was capped with clay. Part of the capped Old TNX Seepage Basin was revegetated and the remainder was covered with asphalt and used for equipment storage. An RFI/RI and BRA have been conducted for the Old TNX Seepage Basin and is summarized in WSRC (1997). 
The New TNX Seepage Basin located east of the TNX Area is an unlined excavation that was constructed in 1980 to replace the Old TNX Seepage Basin. The New TNX Seepage Basin was designed to remove solids from and contain wastewater until it could seep into the underlying sediments that were believed to act as natural ion exchange media to remove chemical constituents. A 0.85 centimeter ( 6 inch) pipe connected the inlet section of the basin to the seepage section. During periods of unusually high discharges, the seepage section of the basin overflowed to outfall X-13A, which, in turn, discharged to a local surface depression. Before using the New TNX Seepage Basin, strict administrative controls were established to ensure that no hazardous waste constituents were disposed of in the TNX Area process sewer system. The New TNX Seepage Basin has received nonhazardous wastewater consisting of primarily inorganic salts. On August 13, 1988, discharges to the New TNX Seepage Basin were rerouted to the TNX Effluent Treatment Plant. An RFI/RI and BRA were conducted and are summarized in WSRC (1997).

The TNX Burying Ground, which is located in the central part of the TNX Area, was used to dispose of debris from the accidental explosion of an experimental evaporator that contained approximately 590 kilograms ( 0.6 tons) of uranyl nitrate. The debris, which included such materials as conduit, drums, tin, and structural steel, was buried in 1953. No additional material was buried at the site after the SRS Radioactive Waste Burial Ground was placed into operation later in 1953. Most of the buried material was excavated and sent to the SRS Radioactive Waste Burial Grounds between 1980 and 1984 during an expansion of the TNX Area. Three known sites of the TNX Burying Ground include an area beneath a transformer pad near Building 673-T, and areas beneath Buildings 711-T and 676-8T. A suspected burial site is located east of Building 673-T. An estimated 27 kilograms (0.03 tons) of uranyl nitrate remains buried at the TNX Burying Ground, constituting 5 percent of the initial inventory. An RFI/RI and BRA were conducted and summarized in WSRC (1997).

The schedule for field activities supporting remediation at the RCRAVCERCLA units described above is contained in the RFI/RI Work Plan for the TNX Area Operable Unit; it includes preparation of a Feasibility Study/Corrective Measures Study to be submitted to regulators by June 26,1998 . The detailed preparation and review schedule for this document is given in WSRC (1997). Remediation of the TNX Operable Unit is not scheduled until the year 2000 (WSRC 1996).

\subsubsection{Site Evaluation Areas}

Nine site evaluation areas have been identified at the TNX Area, including of the following:

CMT-002, Construction Sandblast Area around 677-T Pump Pit

CMT-001, Construction Sandblast Area around 672-T

Combined Spills from 672-T

Combined Spills from 679-T 
Combined Spills from 674-T

Spill on $3 / 17 / 88$ of $<3.8$ liters ( $<1$ gallon) of Sulfuric Acid

Spill on 7/11/84 of 15.1 liters ( 4 gallons) of Process Solution

Neutralization Sump, 678-T

X-001 Drainage Ditch

The site evaluation unit X-001 Drainage Ditch consists of an underground area 3 meters (10 feet) by 1.2 meters ( 4 feet) in a location where a drain line from the Building 677-T Cross Flow Filter Pump Pit emptied into the X-001 drainage ditch. In 1995, the drain line was plugged at both ends when the concrete pit was decontaminated. The top 0.6 meters ( 2 feet) of soil in the drainage pit were removed in an unsuccessful attempt to clean up the area. The ditch is contaminated with uranium, thorium, and their decay products and during clean-up attempts displayed radiological survey readings of up to $25,000 \mathrm{dpm} / 100$ $\mathrm{cm} 2$ at the 0.6 meters ( 2 feet) level. Cleanup efforts were terminated at this point, and the excavation was backfilled with clean soil. This area has been evaluated and moved to Appendix $C$ of the FFA for further action in the appropriate RCRA/CERCLA program. The other eight units remain on Appendix G.1 of the FFA.

\subsubsection{Spills}

Spills that have occurred since 1984 at the TNX Area have been documented. Spilled materials include generally minor quantities of petroleum products, raw materials, or process materials. Significant spill events include 2,271 liters (600 gallons) of diesel fuel in 1984 and 50 grams (1.7 ounces) of mercury from mercury-filled instrumentation in the high bay area of 679-T in 1985. Mercury was found in 1996 during the excavation of the ditches located west of Building 679-T and was removed.

Environmental impacts resulting from spills of process materials are currently being investigated via the site evaluation process.

\subsubsection{Hazardous Materials and Toxic Substances}

\subsubsection{PCBs}

In the late 1970s, SRS developed a program to curtail the use of polychlorinated biphenyl (PCB) transformers and PCB-contaminated electrical equipment. The program included the replacement of large capacitors and other electrical equipment containing PCBs, and the chemical treatment or retrofill of all PCB or PCB contaminated transformers. These were tested to verify that the transformers are now below the $50 \mathrm{ppm}$ level. At this time, all known PCB transformers and large capacitors have been retrofilled.

Smaller oil-containing items are managed as they are removed. These items are managed as PCB suspect equipment unless proven otherwise. 
An inventory performed in the early 1980 s and subsequent enhancements have identified 19 transformers in the TNX Area that have been analyzed and retrofilled as necessary. In addition, 46 switches were identified and analyzed and 2 capacitors were identified and removed.

\subsubsection{Asbestos}

A detailed asbestos inventory was conducted for the TNX Area facilities in 1994. The inspection was performed to provide an inventory of all asbestos containing materials at the TNX Area. The inventory included walkdowns by certified inspectors, personnel interviews, reviews of drawings, and collection and analysis of over 300 samples. Asbestos has been positively identified in the following buildings:

\section{Building $\quad \underline{\text { Location of Asbestos }}$}

679-T outside walls, interior walls of $B$ and $C$ level storage, and part of the roof are transite

679-7T walls and roof are transite

678-T piping insulation in process area (labeled)

677-T inner walls of the weld area, dividing wall of process area are transite. Floors, walls and ceiling of the laboratory are of asbestos-containing material

Outside major segments of steam lines connected to 679-T, 675-T, and 677-T

There have been relatively few maintenance activities in the TNX Area that involved asbestos removal. Asbestos was removed from the ceiling of 679-T in 1991. It is estimated that 30 percent of the original asbestos has been removed. The asbestos remaining is not considered an immediate health hazard as it is in a non-friable state.

\subsubsection{Heavy Metals}

Heavy metals have been used during the lifetime of the TNX Area facilities, and are present as contamination in facilities and equipment. Areas of such contamination include the following:

$\underline{\text { BuildingLocation }}$

$678-\mathrm{T}$

$677-\mathrm{T}$

679-T

$673-\mathrm{T}$
Outside, west of 678-T

Laboratory

Outside, NE Corner in soil

Delphi DETOX process

\section{Contaminant/Remarks}

Mercury, on concrete (painted over)

Mercury

Mercury, to be addressed in site eval

Mercury, in process equipment 
672-T At IDMS facility

At IXF

At $\mathrm{Am} / \mathrm{Cm}$ facility
Mercury, floor vessels are RCRA clean, system flushed

Mercury, low levels

Lead, present in frit

\subsubsection{Chemicals}

\section{Current Chemical Use}

Chemicals are stored in small quantities within the various laboratory areas throughout the TNX Area. Bulk chemicals in larger quantities are primarily contained within tanks used in various experimental process facilities, the 671-T tank farm, and in chemical storage Building 674-T. The TNX Area chemical inventory is listed in SRS Chemical Information and Inventory System (CUS).

Chemical usage information is reported on an annual basis in order to maintain compliance with the requirements of the EPCRA.

\section{Legacy Material}

Substantial quantities of legacy material exist, including chemicals that are either feedstock or products from various large-scale experimental facilities, processes, or laboratories operated at the TNX Area in support of HLW programs such as nitrate and slurry solutions (see Appendix XXI of the EBS for more details). These materials consist of approximately 162,755 liters (43,000 gallons) of material stored in tanks in Buildings 682-T, 671-T, 678-T and 677-T [flushing of these vessels will increase this volume to approximately 264,950 liters (70,000 gallons) and approximately 68,136 liters (18,000 gallons) in 325,208 liter (55 gallon) drums of similar materials stored in 674-1T]. Many of these materials contain hazardous constituents.

TNX Area personnel are currently addressing disposition of these materials through identification, reuse, reprocessing, or disposal, if necessary. All materials will be removed from TNX prior to lease inception.

\subsubsection{Radiological}

Past operations at the TNX Area have resulted in radiological contamination of two TNX buildings. Contaminated areas within 678-T and 677-T include the following:

Building Location

$678-\mathrm{T}$
Old Section, Tank Area

Roof, Rafters
Type of Contamination/Remarks

fixed, under paint, abandoned in place 
Laboratory, upstairs

Under floor

Sump, old section

Outside, west

Outside, east

$677-\mathrm{T}$

\author{
U IV facility \\ Mixer Settler \\ Contactor Facility \\ Outside, south \\ Laboratory
}

inside cabinets

identified when digging footers

for annex

under floor, annex

fixed, under paint

location of old evaporator

west annex, abandoned in place

abandoned in place

abandoned in place

tankage

interior of cabinets

Contaminated facilities within Building 677-T are segregated into high contamination areas (HCAs), contamination areas (CAs), and radiological buffer areas (RBAs). Contaminated facilities within Building 678-T are identified CAs and RBAs. Administrative and institutional controls (including physical barriers) will be in place to prevent contact between workers and the contaminated equipment and facilities. Details of these controls will be described in the lease agreement.

\subsubsection{Waste Management}

\subsubsection{Solid Waste}

Solid waste is generated from pilot scale research, maintenance, and laboratory operations at the TNX Area. Solid waste is segregated into separate dumpsters located throughout the TNX Area. These include paper, cardboard, and municipal waste. Industrial materials are segregated in skip pans designated for metal, wood, and treated lumber. Solid waste is managed on a sitewide basis, and routine pickups are made within the TNX Area.

\subsubsection{Hazardous Waste}

Hazardous waste is generated from pilot scale research, maintenance, and laboratory operations at the TNX Area. One staging and 16 satellite accumulation areas existed at the TNX Area at the time of the WSRC (1997) survey. Wastes accumulated in these areas include toxic, corrosive, flammable, reactive, or listed wastes. Hazardous waste is dispositioned by transport to a centrally located permitted storage facility, or direct transport to a waste handler.

\subsubsection{Radioactive Waste}

Low-level radioactive job-control waste is generated from within contaminated areas at the TNX Area. This material is accumulated in a metal B-25 container located in a Radiological Material Area (RMA) across the road from the southwest corner of Building 
677-T. This material is transported periodically to a centrally located storage facility at E Area on SRS.

\subsection{ENVIRONMENTAL CONSEQUENCES OF THE PROPOSED ACTION AND ALTERNATIVES}

\subsection{Safety and Health Impacts}

DOE-SR would require that the management firm of the MPPC ensure sub-lessees of facilities comply with OSHA, NFPA 20 Life Safety Codes, Emergency Management, Radiation Control, and all environmental, safety, and health laws and regulations. DOE-SR would provide the oversight for compliance activities related to requirements for OSHA. As a result of external reviews, issues and findings would be addressed by the management firm and corrective action plans would be prepared and implemented.

DOE-SR will require the management firm, as part of the contract instrument, to ensure sub-lessees of facilities submit an Environment, Safety and Health (ES\&H) Plan that includes the ES\&H standards and requirements that would be applied in the conduct of work under the agreement. The ES\&H would be developed based on the scope of work and associated hazards to provide adequate protection for the health and safety of workers, the public, and the environment. DOE-SR would retain the discretion to check on the management firm to ensure its performance meets the requirements provided in the plan and will reserve authority to terminate the agreement in the event of unsatisfactory performance.

Effluents/emissions from the activities of the management firm and its tenants will not be allowed to exceed permitted limits. Any desired deviations from SRS permit requirements would require DOE-SR and State approval. The management firm will be responsible for reporting and responding to all non-permitted environmental releases.

DOE-SR would make the management firm responsible for administering a chemical management program for the campus. This would entail coordination and management of chemicals required to support both infrastructure and R\&D facilities (laboratories, process areas, warehouse space, etc.). The coordination would include preparation and submittal of the annual inventory, and managing the hazardous waste satellite and staging areas in accordance with applicable Federal and State laws and regulations. The management firm would be responsible for coordinating the disposition of all hazardous and domestic waste.

Management of the campus maintenance organization would consist of work control, material procurement, and maintenance (mechanical, electrical, and instrumentation) personnel. This would include maintenance and support of the infrastructure to ensure adequate and reliable facilities to accomplish current and future research, and development, demonstration and commercial activities. 
DOE-SR would have the management firm responsibilities consist of shift operations, day operations, and area services, as appropriate. Responsibilities would include:

- Initiate and implement job planning systems

- Review and approve work priority

- Evaluate and monitor industrial safety posture

- Establish required job plans and/or procedures

- Hazardous Energy Control (HEC)

- Initiate, review and approve equipment/facility start up plans

- Provide routine off-shift surveillance and equipment monitoring, chemical sampling, fire watch surveillance and property protection (security) surveillance of facilities.

Engineering support would be required to provide technical oversight of facilities and equipment. The management firm would coordinate and maintain the overall facility authorization basis documentation to ensure proper hazard classification of the facility and systems to include providing some level of engineering support. The management firm would serve as Design Authority for infrastructure, facilities and services, as well as, insuring that appropriate documentation is in place for an Environmental Evaluation Checklist (EEC). The management firm would submit any plans for infrastructure or design changes to DOE-SR for its approval prior to commencement of work. This would ensure that the changes are architecturally consistent with the surrounding structures and SRS. In addition, engineering support would be required to develop and review procedures for proposed $R \& D$ experimental activities.

DOE-SR would provide emergency responses through compliance with DOE Order 5500 series to respond to any onsite incidents at SRS. Campus lessees would be required to report all events (i.e., spills, releases, personnel contamination, etc.) to the management firm. The management firm would respond and notify other SRS organizations (such as the SRS Operations Center (SRSOC), Fire Department, and HAZMAT Team) as warranted. Appropriate and timely response to environmental events (i.e., chemical spills or inadvertent releases) is essential to ensuring adequate protection of human health and the environment and particularly in view of the variety and quantities of chemicals.

DOE-SR would have property management for material and equipment at the campus be a management firm function. A program to protect government property including accountability of equipment (computers, office equipment, etc.) would be established.

Existing environmental permits would remain under DOE-SR.

Currently, two large scale demonstrations, the $\mathrm{Am} / \mathrm{Cm}$ melter development work at Building 672-T and the Delphi demonstration to detoxify liquid and hazardous waste in Building 673-T will continue until mid-1998. The smaller-scale Ener Tech demonstration will conclude in 1998 . These demonstrations currently operate well within existing permit limits. 
The types of activities and businesses that are planned at the MPPC would include R\&D in the areas of environmental remediation; waste management and vitrification of non-radioactive waste; metal fabrication and machining operations; and production of chemicals and polymers. Some pilot-scale manufacturing is expected.

To forecast the types of lessees that might occupy space or facilities at the MPPC at SRS, the products of the companies that make up the DOE Oak Ridge, Tennessee reindustrialization effort at the DOE Oak Ridge Site are listed below:

- Chemical and physical treatment of hazardous wastes to eliminate hazards and meet requirements for offsite land disposal.

- Box manufacturing

- Manufacture special infrared furnaces and contract heat treatment work

- Machining

- Decontamination of components and industrial machinery

- Container testing

- Engineering/construction

- Asbestos destruction

- Electrical personal protective equipment testing

- Manufacture of inorganic membrane filter tubes

- Materials recycling

These companies/products and their potential environmental impacts are expected to be typical of those companies/products that would occupy the MPPC. Effluents/emissions from the lessees that may occupy TNX will not be allowed to exceed permitted limits. The effluents/emissions are expected to have less potential environmental impacts than previous TNX operations. This is because of the extensive radiological work conducted at TNX in the past.

\section{Summary of Impacts of Past Operations of TNX and Existing Permit Conditions}

Some areas within Buildings $677-\mathrm{T}$ and $678-\mathrm{T}$ contain radiological contamination from depleted uranium. Contaminated equipment is located in these areas. Administrative and institutional controls would be in place to prevent contact between workers and the contaminated equipment before occupancy of these buildings. No new radiological R\&D is planned for TNX.

Environmental permits are in place from SCDHEC for the TNX Area air emissions, storm water, process water, and industrial wastewater treatment facilities (which include a process effluent treatment facility and sanitary wastewater treatment facility).

Remediation at TNX is being conducted through the FFA by DOE-SR, which integrates the RCRA and the CERCLA remediation processes. The four RCRA/CERCLA units at TNX include TNX groundwater, the Old TNX Seepage Basin, the New TNX Seepage Basin, and the TNX Burying Ground. These four units are collectively identified as the 
TNX Operable Unit. The Work Plan for TNX has been submitted and characterization of the soils has been completed. There are some outstanding issues regarding groundwater in the wetlands, which would not impact leasing of the TNX Area buildings. Remediation for the TNX Operable Unit is not scheduled until 2000 (Wilson 1997).

The Water Table Aquifer is about 7.6 meters ( 25 feet) below ground surface throughout much of the TNX Area Operable Unit and outcrops in the TNX swamp. Corrective action for TNX groundwater, approved by USEPA, SCDHEC, and DOE in 1994 through an IROD, was implemented in 1996 and consists of four recovery wells and a groundwater air stripper. The pump and treat system is designed to inhibit further migration of elevated levels of VOCs to the swamp outside the fenced area. Other remediation technologies are being evaluated in the event that the Interim Remedial Action does not adequately address the contamination. The Gordon Aquifer is a semi-confined aquifer beneath the TNX Area Operable Unit and should not be impacted by the proposed action as any groundwater action would be reviewed by DOE-SR.

The Old TNX Seepage Basin, constructed in 1950 and removed from service in 1980, is an unlined excavation used to remove solids from and contain wastewater until it could seep into the underlying sediments that were believed to act as natural ion exchange media to remove chemical constituents. In 1981, the west wall of the basin was breached to drain the impounded liquids to nearby wetlands; the basin was backfilled and capped and not considered a concern within the fenced area of TNX.

The TNX Burying Ground was used to dispose of debris from the accidental explosion of an experimental evaporator containing uranyl nitrate. Most of the buried material was excavated during an expansion of the TNX Area; however three known and one suspected burial sites remain. These are estimated to contain 27 kilograms ( 0.03 tons) of uranyl nitrate and are under remedial investigation.

An RFI/RI and BRA have been conducted for the TNX Area Operable Unit; the report summarizing this investigation and assessment was published in May 1997. Analyses of data from the investigation was initiated with the identification of Unit Specific Constituents (USCs). Fate and transport analyses were conducted of the USCs, from which Contaminant Migration Constituents of Potential Concern (CMCOPCs) were identified. Detailed modeling and subsequent uncertainty analyses further narrowed the list to a list of human health Constituents of Concern (COCs). A Human Health Risk Assessment was performed on the identified human health COCs to identify those that should be retained at the specific site.

An Ecological Risk Assessment was also performed as part of the BRA by evaluation of Hazard Quotients for current and future exposure of ecological receptors to Constituents of Potential Concern (COPCs). Uncertainty analyses were performed to identify those COCs to be retained at the specific site. 
Field activities supporting remediation at identified RCRA/CERCLA units will continue per the FFA with the preparation of a Feasibility Study/Corrective Measures Study (FS/CMS), scheduled to be submitted to regulators on April 24, 1998. The current schedule calls for a ROD in June 1999 and initiation of a Remedial Action in September 2000 .

In addition to the four RCRA/CERCLA units, nine FFA site evaluation areas are present in the TNX Area and are currently being investigated.

Nineteen transformers in the TNX Area were analyzed for PCBs and retrofilled as necessary. In addition, all other large PCB-contaminated equipment was identified and removed.

An asbestos survey of TNX Area facilities was performed in 1994. Asbestos is present in four process buildings and along steam lines within the area. Little asbestos removal has been performed, as the remaining material is in a non-friable state; asbestos is not considered an immediate health hazard.

Heavy metal contamination, consisting of mercury and lead, is present in some equipment and facilities within the TNX Area. Administrative and institutional controls are in place to protect workers.

Previous operations at TNX did not require DOE-SR to install sprinkler systems as part of the NFPA standards. If the proposed action requires changes in process or locations of personnel, NFPA Life Safety Code sprinkler systems and an upgrade of the fire pumps may be required.

The TNX Area is located approximately 0.8 kilometer $(0.5$ mile $)$ east of the Savannah River and is bordered outside of the fenced area by wetlands. No wetlands exist within the area designated for the proposed action, thus, no adverse impacts are anticipated.

About 120 individuals are currently occupying the TNX Area (Hayford 1997). During its peak occupancy in 1989, about 250 people worked at TNX (Norton 1989). The proposed action would result in an increase in personnel which would likely be similar to peak periods of previous occupation resulting in minimal impacts to the infrastructure of TNX. For example, the sanitary waste water treatment plant at TNX is sized to handle 800 people and is currently underutilized. There may be a slight increase in the local economy due to material and supply purchases by lessees, but it is expected to be of minimal impact on the economy in the surrounding area.

Transportation of any hazardous materials to and from the MPPC would meet Department of Transportation (DOT) regulations and would be monitored by DOE-SR under DOE Orders as on other SRS roads. 
The current traffic volume (i.e., 1700 vehicles per day) is considerably below the design maximum capacity of Road 3 leading from SC Route 125 to TNX which is in excess of 2800 vehicles per hour. During the peak operation of TNX in the 1988-1989 timeframe, the number of vehicles per 24 hours on SC Route 125 near Road 3 was 449 with a minimum accident rate (Swygert 1997). The proposed action would have minimal impact on the accident rate and the number of vehicles on SC Route 125 as the vehicle increase under the proposed action would be similar to the numbers occurring during the 1988-1989 timeframe. The accident rate during this timeframe was considered minimal.

The management firm for the MPPC would determine, in agreement with DOE-SR, what the badging requirements would be to gain easier access to inside the MPPC fenced area via the manned traffic barricade on Road 3 leading from SC Route 125 to TNX.

No archaeological sites would be disturbed as a result of the proposed action as no significant sites within the fenced area of TNX and no borings or soil disturbances are anticipated due to lessee activities.

A Biological Assessment by the U.S. Forest Service Savannah River Natural Resource Management and Research Institute resulted in an expected "No Effect" on existing proposed, threatened, and endangered species in the MPPC Area. No sensitive plant species were reported (LeMaster 1997). The U.S. Fish and Wildlife Service (USFWS 1997), concurred with this determination that the proposed action will not likely affect listed or proposed endangered or threatened species and would not likely have significant adverse wetland impacts.

\subsection{Human Health Effects}

OSHA regulations (29 CFR Part 1910) require that employers comply with safety and health standards set by the act to provide each employee with a worksite that is free from recognized hazards that are likely to cause death or serious injury. Personal protective clothing and equipment would be used as appropriate. DOE-SR would require an ES\&H Plan for each facility sub-lessee to ensure protection for the health and safety of the workers, the public, and the environment. Work involving radiological contamination will require approval and review by the DOE-SR Radiation Protection Division. Work should be conducted in accordance with DOE Order 5480.10. Extensive human health and ecological risk assessments have been conducted as part of the ongoing RCRA/CERCLA remedial investigations under the FFA at TNX. The contaminants have been identified and remediation scheduled. Administrative and institutional controls are in place to protect workers. Therefore, human health impacts would be minimal. 


\subsection{Environmental Consequences of the Alternatives}

Under the no-action alternative, the intent of the ICAR legislations would not be met, no new technologies would be developed, and the TNX facility would continue to be underutilized and would not be cost effective to operate over the long term without new missions. Funding of new missions for TNX is not anticipated in the foreseeable future. The Accelerator Production of Tritium project, for example, does not plan to use the TNX facilities. It is likely TNX would be shutdown, its infrastructure and resources dismantled, and eventually decontaminated and decommissioned. The no-action alternative would not preserve the TNX Area for future SRS support missions. A TNX "Transition Plan" (Hayford and Bokesch 1997) is in place that addresses several issues from the past years of operation, downsizing, and cost reducing asset management that would be completed under the no-action alternative.

Personnel would likely be reassigned to other site tasks. The no-action alternative would have none of the potential impacts associated with the proposed action. There would be no increase in traffic on the local roads. None of the existing permits would likely need to be modified until facility shutdown.

Use of other DOE-SR facilities for the Centers of Excellence, such as M Area or the reactor areas, does not provide ready access for commercial activities and lacks the necessary infrastructure. These areas are not near a major public access making materials transportation more difficult. Also, an EBS has not been initiated for these areas.

The alternative to locate the Centers of Excellence outside of SRS within the five county area would not allow direct study of site contamination and the development of site-specific cleanup technologies to bring to commercialization. Also, there are not enough funds provided in the ICAR legislation budget to fund new facilities either on or offsite. There are also limited laboratory facilities within the five county area and needed access to cleanup technologies being utilized at the Three Rivers Solid Waste Authority Regional Landfill would be more difficult if the Centers were located away from SRS. Environmental permits would need to be obtained from the State.

\subsection{Cumulative Impacts}

The primary cumulative impacts from the proposed action would be those effects associated with the emissions, effluents, and wastes from multiple sources from the numerous lessees' operations. The management firm and its tenants would operate in compliance with all applicable SRS environmental permits, unless alternate administrative arrangements can be made.

There would be minimal effect on the local economy with some increase in the purchases of materials and supplies from the proposed action. No additional adverse impacts are expected to either the site surface or groundwater quality. RCRA/CERCLA remedial actions would proceed under the FFA schedule with administrative and institutional 
controls in place to assure minimum health and safety risks to workers and non-interference between lessees' operations and environmental restoration activities. The proposed action would have no adverse effects on threatened and endangered species, cultural resources, floodplain, or wetlands at SRS. Additional impacts to local air and water quality would be negligible. Any plans for expansion of existing facilities or processes would be reviewed and approved by DOE-SR and require appropriate permits and additional NEPA reviews. The MPPC would be required to be monitored for ES\&H requirements through an ES\&H Plan. The requirements are the same as the site's in order to assure that there are no additional potential problems for either public health or safety. There would be no change in the latent fatal cancers within the region as the result of the proposed action. Any increases in site traffic accident and fatality rates would be minimal as the result of the proposed action.

\subsection{REGULATORY AND PERMITTING PROVISIONS CONSIDERED}

DOE policy is to carry out its operations in compliance with all applicable Federal, State, and local laws and regulations, as well as all DOE Orders. This section provides a discussion of the major regulatory permits and plans that are applicable to the proposed action.

\subsection{National Environmental Policy Act of 1969 as amended}

This EA has been prepared in compliance with the NEPA of 1969, as amended, and the requirements of the Council of Environmental Quality (CEQ) Regulations for Implementing NEPA (40 CFR Parts 1500-1508), and DOE Regulations (10 CFR Part 1021), and DOE Order 451.1A. NEPA, as amended, requires "all agencies of the Federal Government" to prepare a detailed statement on the environmental effects of proposed "major Federal actions significantly affecting the quality of the human environment." This EA has been written to comply with NEPA and assess the potential environmental impacts of privatizing the TNX Area and to operate it as Centers of Excellence in a MPPC.

\subsection{Environmental Baseline Survey: Summary of TNX Regulatory Compliance Activities}

The SRS Environmental Baseline Survey Report for the TNX Area (WSRC 1997) was submitted to USEPA Region IV and to SCDHEC for approval of a determination of suitability to lease the property consistent with CERFA and NDAA. The EBS summarized all of the environmental compliance permits, inventories, surveys, logs and plans in a series of appendices attached to the report. Pertinent appendices which relate specifically to regulatory compliance for the proposed action are listed below and are included to illustrate the well documented environment in the TNX Area: 
- $\quad$ RFI/RI Report with Baseline Risk Assessment for the TNX Area Operable Unit

- TNX Air Quality Control Operating Permit

- Air Emissions Inventory for TNX

- EPCRA Release Report for TNX

- $\quad$ SRS NPDES Stormwater Permit

- TNX SPPP

- Outfall X-8 Toxicity Documentation

- $\quad$ NPDES Industrial Wastewater Permit for TNX Outfalls

- TNX Spill Control and Countermeasures Plan

- TNX Best Management Practices Plan

- TNX Industrial Wastewater Operating Permit Log Sheets

- Characterization of Shallow Groundwater at TNX

- FFA

- Schedule for RFI/RI Activities and Document Submittals for the TNX Area Operable Unit

- TNX Spill Reports

- TNX PCB Inventory

- TNX Asbestos Survey Report

- TNX Chemical Inventory

- $\quad$ TNX Chemical Usage Report

- TNX Legacy Materials

- TNX Waste Characterization Plan

- TNX Hazards Assessment Document

- Radiological Survey of TNX

- TNX Satellite/Staging Area Inventory

\subsection{AGENCIES AND PERSONS CONSULTED}

The United States Fish and Wildlife Service and the U.S. Forest Service Savannah River Natural Resources Management and Research Institute were consulted in the preparation of this EA. 
Arnett, M. W., and A. R. Mamatey (eds.), 1997. Savannah River Site Environmental Report for 1996. WSRC-TR-97-071. Westinghouse Savannah River Company, Savannah River Site, Aiken, South Carolina.

Bauer, L. R., D. W. Hayes, C. H. Hunter, W. L. Marter, and R. A. Moyer, 1989. Reactor Operation Environmental Information Document, Volume III: Meteorology, Surface Hydrology, Transport and Impacts (U), WSRC-89-817, Westinghouse Savannah River Company, Savannah River Site, Aiken, South Carolina.

DOE (U.S. Department of Energy), 1995. Environmental Assessment for the Construction and Operation of the Three Rivers Solid Waste Authority Regional Waste Management Center at the Savannah River Site. DOE/EA-1079, Savannah River Operations Office, Savannah River Site, Aiken, South Carolina.

DOE (U.S. Department of Energy), 1997a. Harnessing the Market: The Opportunities and Challenges of Privatization. A Report to the Secretary of Energy. DOE/S-0120. The Department of Energy, Washington, DC.

DOE (U.S. Department of Energy), 1997b. Draft Guidance on the NEPA Process in the Privatization Context. EH-42, Waste Activities Division, Office of NEPA Policy and Assistance, The Department of Energy, Washington, DC.

DOE (U.S. Department of Energy), 1997c. Shutdown of the River Water System at the Savannah River Site, DOE/EIS-0268, Savannah River Operations Office, Aiken, South Carolina.

Haselow, J. S., V. Price, D. E. Stephenson, H. W. Bledsoe, and B. B. Looney, 1989. Reactor Operation Environmental Information Document, Volume I: Geology, Seismology and Subsurface Hydrology (U), WSRC-89-815, Westinghouse Savannah River Company, Savannah River Site, Aiken, South Carolina.

Hayford, G. F., 1997. TNX Operations, Westinghouse Savannah River Company, Aiken, S.C., Personal communication with B. C. Marcy, Westinghouse Savannah River Company, Aiken, South Carolina, TNX Operations Data.

Hayford, G. F. and D. M. Bokesch, 1997. The TNX Transition Plan. TSD-TNX-97-040. Westinghouse Savannah River Company, Aiken, South Carolina.

HNUS (Halliburton NUS Environmental Corporation), 1997. Socioeconomic Characteristics of Selected Counties and Communities Adjacent to the Savannah River Site. Halliburton NUS Corporation, Aiken, South Carolina. 
LeMaster, E. T., 1997. Savannah River Natural Resource Management and Research Institute, Aiken, SC, letter to B. C. Marcy, Westinghouse Savannah River Company, Aiken, S.C. Threatened, Endangered, and Sensitive Species Listing and Habitat Evaluation for the Proposed Multi-Purpose Pilot Plant Campus in T-Area, October, 1997.

Mayer, J. J., and L. D. Wike, 1997. SRS Urban Wildlife: Environmental Information Document, WSRC-TR-97-0093, Westinghouse Savannah River Company, Savannah River Site, Aiken, South Carolina.

Norton, N., 1989. Westinghouse Savannah River Company, Aiken, SC, Technical Division, Savannah River Laboratory, Interoffice Memorandum to W. L. Tamosaites, et. al, Westinghouse Savannah River Company, Aiken, South Carolina, TNX Organization Chart.

Swygert, R. W., 1997. Engineering Services, Westinghouse Savannah River Company, Aiken, S.C., Personal communication with B. C. Marcy, Westinghouse Savannah River Company, Aiken, South Carolina, SRS Traffic Information Near Route 125 and TNX.

USFWS (U.S. Fish and Wildlife Service), 1997. Confirmation of Not Likely to Adversely Affect Proposed, Endangered, and Threatened Species (PETS) for the Reuse of TNX as a Multi-Purpose Pilot Plant Project Campus on the Savannah River Site in Aiken County, South Carolina. Letter from Stephen A. Danker, Engineering and Analysis Division, U.S. Department of Energy, Savannah River Operations Office, Aiken, South Carolina to Roger Banks, U.S. Department of Interior, Fish and Wildlife Service, Charleston, South Carolina, December 9, 1997. Confirmation signed by L. Duncan, Acting Field Supervisor, January 5, 1998.

Wike, L. D., R. W. Shipley, A. L. Bryan, J. A. Bowers, C. L. Cummins, B. R. del Carmen, G. P. Friday, J. E. Irwin, J. J. Mayer, E. A. Nelson, M. H. Paller, V. A. Rogers, W. L. Specht, and E. W. Wilde, 1994. SRS Ecology: Environmental Information Document, WSRC-TR-93-496, Westinghouse Savannah River Company, Savannah River Site, Aiken, South Carolina.

Wilson, M. P., 1997. Environmental Protection Department, Westinghouse Savannah River Company, Aiken, S.C., personal communication with B. C. Marcy, Westinghouse Savannah River Company, Aiken, South Carolina, Schedule for Remediation of the TNX Operable Unit, October 1997.

WSRC (Westinghouse Savannah River Company, 1996. Savannah River Site Plan for Performing Maintenance in Federal Facility Agreement Areas (O\&M Plan), WSRC-RP-96-45. Westinghouse Savannah River Company, Aiken, South Carolina 
WSRC (Westinghouse Savannah River Company), 1997. Savannah River Site Environmental Baseline Survey Report. WSRC-RP-97-350. Westinghouse Savannah River Company, Aiken, South Carolina. 